\title{
Prosedürel Adalet Algısı ve Örgütsel Özdeşleşme Arasındaki İlişki: Etik Liderliğin Aracılık Rolü

\author{
(The Relationship Between the Perception of Procedural Fairness and the Organizational \\ Identification: The Mediating Role of Ethical Leadership)
}

\section{Seval AKSOY KÜRÜ iD a}

a Gebze Teknik Üniversitesi, Sosyal Bilimler Enstitüsü, İşletme Ana Bilim Dalı, İşletme Bölümü, Kocaeli, Türkiye. drsevalaksoykuru@gmail.com

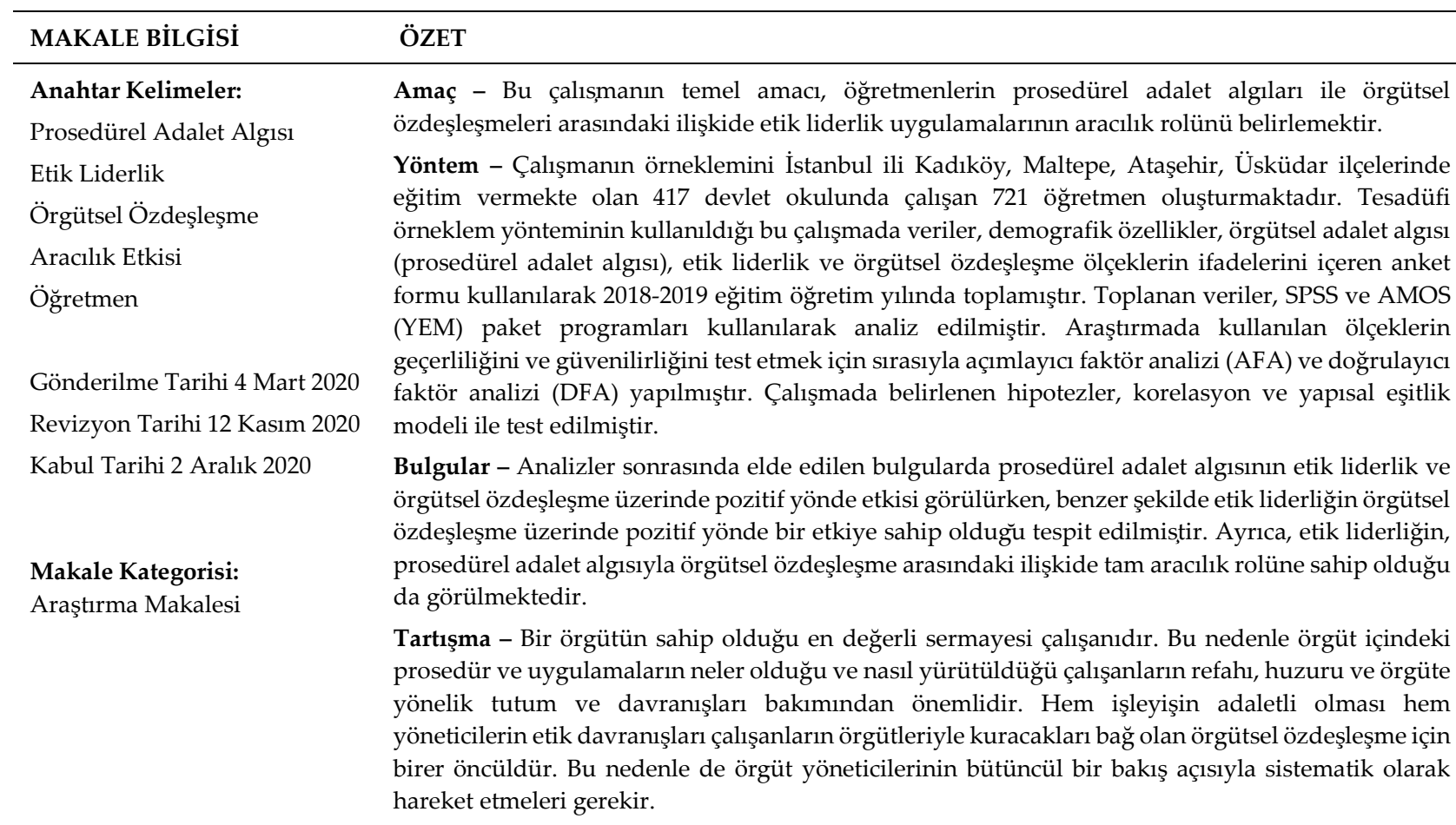

\begin{tabular}{|c|c|}
\hline ARTICLE INFO & ABSTRACT \\
\hline $\begin{array}{l}\text { Keywords: } \\
\text { Perception of Procedural } \\
\text { Fairness }\end{array}$ & $\begin{array}{l}\text { Purpose - The main purpose of this study is to determine the mediating role of ethical leadership } \\
\text { practices in the relationship between teachers' perceptions of procedural justice and their } \\
\text { organizational identification. }\end{array}$ \\
\hline $\begin{array}{l}\text { Ethical Leadership } \\
\text { Organizational Identification } \\
\text { Mediating Effect, Teacher }\end{array}$ & $\begin{array}{l}\text { Design/methodology/approach - The sample of the study consists of } 721 \text { teachers working in } 417 \\
\text { public schools teaching in Kadıköy, Maltepe, Ataşehir, and Üsküdar districts of Istanbul. In this } \\
\text { study, in which the random sampling method was used, the data were collected in the 2018-2019 } \\
\text { academic year using a questionnaire containing the expressions of demographic characteristics, } \\
\text { organizational justice perception (procedural justice perception), ethical leadership, and } \\
\text { organizational identification scales. The collected data were analyzed using SPSS and AMOS (YEM) } \\
\text { package programs. In order to test the validity and reliability of the scales used in the study, } \\
\text { exploratory factor analysis (EFA) and confirmatory factor analysis (CFA) were performed, } \\
\text { respectively. The hypotheses determined in the study were tested with the correlation and structural } \\
\text { equation model. }\end{array}$ \\
\hline $\begin{array}{l}\text { Article Classification: } \\
\text { Research Article }\end{array}$ & $\begin{array}{l}\text { Findings - In the findings obtained after the analysis, while the positive effect of procedural justice } \\
\text { perception on ethical leadership and organizational identification was observed, similarly, it was } \\
\text { determined that ethical leadership perception had a positive effect on organizational identification. } \\
\text { It is also seen that ethical leadership has a fully mediating role in the relationship between } \\
\text { procedural justice perception and organizational identification. }\end{array}$ \\
\hline
\end{tabular}

\section{Önerilen Atıf/ Suggested Citation}

Aksoy Kürü, S. (2020). Prosedürel Adalet Algısı ve Örgütsel Özdeşleşme Arasındaki İlişki: Etik Liderliğin Aracılık Rolü, İşletme Araştırmaları Dergisi, 12 (4), 3895-3913. 
Discussion - The most valuable capital an organization has is its employee. For this reason, what the procedures and practices within the organization are and how they are carried out are important for the welfare, peace and attitude and behavior towards the organization. Both the fairness of the functioning and the ethical behaviors of the managers are the antecedents for organizational identification, which is the bond that employees will establish with their organizations. For this reason, the managers of the organization should act systematically with a holistic perspective.

\section{Giriş}

Hizmet sektörünün temel yapı taşlarından belki de en önemlisi olan eğitim öğretim sektörü, insanın insana doğrudan hizmet ettiği ve makineleşme kanalıyla tek tip bir yapının mümkün olamayacağı okul ortamına sahiptir. Bu tür örgütler için hem öğretmenlerin yüksek düzeyde performans sergileyebilmeleri hem örgüte yönelik aidiyet oluşturarak bunu kalıcı kılabilmenin hem de örgütten ayrılmanın ortadan kaldırılabilmesi önem taşımaktadır. Bu nedenle de mevcut koşulların detaylı olarak incelenip değerlendirilmesi, gerekli görülen durumlarda iyileştirilmelerin hızlıca yapılabilmesi ve belki de en önemli unsurlardan biri olarak ise yöneticinin liderlik vasıflarının ele alınması gerekmektedir. Bu sayede, bir okul ortamı için adaletli bir çalışma ortamının ve ahlaki değerleri yüksek olan hakkaniyet sahibi bir liderin varlı̆̆ı çok kıymetlidir denebilir.

Yönetim ve organizasyon ile örgütsel davranış yazınına bakıldığında daha çok örgütsel bağlılık, performans, iş tatmini, vb. konuların ele alındığı; çalışan bireylerin psikolojik yönlerine özellikle değinen örgütsel özdeşleşmeye gereken önemin 1970'li yıllar itibariyle verildiği görülmektedir. Hatta, örgütsel özdeşleşme konulu çalışmalar 2000'li yıllara kadar oldukça az sayıdadır. Riketta'nın (2005: 359) yaptığı meta-analizi çalışmasında da bu açıkça görülmektedir. Konuya yönelik olarak düşük düzeyde seyreden önemin günümüzde artış göstermesinin temel nedeni, örgütlerin daha iç içe ve organik bir yapıya bürünmüş olmaları ve çevrelerinin çok daha karmaşık bir hal almasıdır (Alberth, vd. 2000: 13). Örgütsel davranış yazınında önemli bir yeri olan Lee'ye (1971: 213) göre de çalışan bireylerin duygu durumlarının analiz edilmesi, bu sayede aidiyet ve sadakat düzeylerinin tespiti ve örgütsel kimlik edinimlerinin olmazsa olmaz hale gelmesi örgütsel özdeşleşme kavramının önemle ele alınmasında bir itici güçtür. Çünkü bireylerin üyesi oldukları örgütlerinin yapısı, yönetim tarzları ve ekonomik koşulları nedeniyle örgütlerine duydukları sadakatlerinin ve aidiyetlerinin bozulmaya ve hatta zamanla azalmaya başlaması belli başlı bazı çözüm önerilerini de doğurmuştur (Mael ve Ashforth, 1992: 103; Van Knippenberg ve Van Schie, 2000: 137). Bu nedenle de örgütsel özdeşleşme kavramı, bireyle örgüt arasındaki bağın ne düzeyde olduğunun ortaya konulmasında oldukça kıymetli bir psikolojik unsur haline dönüşmüştür (Edwards, 2005: 207; Riketta ve Van Dick, 2005: 491). Ayrıca, kazanımlar ve bunların kazanılma sürecinin aynı sonuç gibi değerlendiriliyor olmasından dolayı dağıtım adaleti algısıyla oluşan yüksek korelasyon (Folger, 1987; Sweeney ve McFarlin 1997; Welbourne vd., 1995; Martocchio ve Judge 1995; Cropanzano ve Ambrose 2001; Colquitt, 2001) ve etik liderliğin süreçle çok daha fazla alakadar olması nedeniyle, örgütsel adalet algısının yalnızca prosedürel adalet algısı boyutu incelenmiştir.

Bu çalışmadaki temel amaç, eğitim öğretim sektörünün temel yapı taşı olan okullardaki öğretmenlerin, okul yönetiminin benimsediği yönetim anlayışının ve öğretmenlere hissettirdikleri örgütsel adalet algısının örgütsel özdeşleşmenin oluşmasında ne denli belirleyici ve hatta katkı sağlayıcı unsurlarının olup olmadığının ortaya konulması ve bu ilişkide de etik liderlik uygulamalarının aracılık rolünün tespit edilmesidir. Ayrıca, yazında örgütsel adalet algısının ve yönetimde etik liderlik uygulamalarının birlikte örgütsel özdeşleşme üzerindeki etkisinin eğitim sektöründe incelendiği bir çalışmaya rastlanılmamıştır. Bundan dolay, bu alanda bir eksiklik görülmüş olması bu çalışmanın yapılması için bir diğer gerekliliği oluşturmaktadır.

\section{KAVRAMSAL ÇERÇEVE}

\subsection{Prosedürel Adalet Algısı}

Kökleri dinden, felsefeden ve siyaset biliminden gelen ve çok yönlü bir yapıya sahip olan adalet kavramı, Sokrates ve Platon'dan günümüze kadar çok sayıda bilim insanı ve filozofun ele aldığı bir konudur. Adalet, her dönemin ve her bilim dalının içinde bulunduğu durumlara, değerlendirme ölçütlerine, adaletin varlığına veya yokluğuna yüklenen anlamlara ve adalete yönelik bakış açılarına göre farklı manalar taşımaktadır. Genel anlamda hak, adillik ve eşitlik olarak anılan adalet kavramı Türk Dil Kurumu'nun (2020) tanımlamasına göre, "hak ve hukuka uygunluk, hakkı gözetme; herkese kendine uygun düşeni, kendi hakkı olanı verme, dŏ̆ruluk" anlamına gelmektedir. Adaletin 1900'lerin ortasından itibaren örgütlerde anılması ise örgütsel adalet kavramıla karşımıza çıkmaktadır. Öncelikle Greenberg (1990) tarafından ele alınan örgütsel adalet, "işgörenlerin işlerinde 


\section{S. Aksoy Kürü 12/4 (2020) 3895-3913}

kendilerine adil davranılı davranılmadığına nasıl karar verdikleriyle ve bu kararların işle ilgili diğer değişkenleri nasıl etkilediğiyle ilişkisidir" (Moorman, 1991: 845) ifadesiyle tanımlanabilmektedir.

Örgüt içindeki politikaların ve uygulamaların adil olup olmama durumunun bütün olarak değerlendirilebilmesinin mümkün olmaması nedeniyle yaygın olarak üç alt boyutta (Alexander ve Ruderman, 1987; Greenberg, 1987, 1988, 1993, 1996; Lind, 1995, Lind ve Tyler, 1988; Fryxell ve Gordon, 1989; Folger ve Konovsky, 1989; Tornblom,1990; Sheppard vd., 1992; Cropanzano ve Randall, 1993; Gordon ve Fryxell, 1993; Hartley, 1995; Alexander vd., 1995; Taylor vd.,1995; Cropanzano ve Kackmar, 1995; Beugre, 1998; Folger ve Cropanzano, 1998; Chang, 2002) ele alınan örgütsel adalet alg1sı, öncelikle dağıtımsal adalet algısı boyutunu incelemiştir. Adams'in (1965) Hakkaniyet Teorisi'nden kök alan bu boyut (Gilliland ve Chan, 2009: 169), örgütte var olan kaynakların adil bir biçimde paylaştırılmasını ifade etmektedir (Greenberg, 1987: 17, 1990: 423; Castillo ve Fernandez, 2017: 285). Çalışanların ödül, ceza, terfi ve maaş gibi çıtıları nasıl değerlendirdikleriyle alakalı olan dağıtımsal adalet algısının (Srivastava, 2015: 668) eksik kaldığı durumlara bağlı olarak ortaya konulan prosedürel adalet algısı ise, örgütün kaynaklarını elde ederken yaşanan süreçteki adalet düzeyinin yorumlandığı ve buna dair bilgiyi ifade etmektedir (İyigün, 2012: 58). Burada önemli olan nokta, kaynak veya çıktı dağıtımının yapılıp yapılmamasından çok hangi yöntemlere, gerekçelere ve nedenlere göre yapılıp yapılmadığıdır. Yani, izlenen bir prosedür(ler) var mıdır? Varsa bu prosedürün tarafsızlıkla, karşılıklı iletişime dayalı etkileşimle, çalışanlara görüş bildirmeyle ve söz hakkı tanımayla, dürüstlük ve samimiyet içermeyle ve nihayetinde de uzlaşmayla ilgili olduğu bir süreçten bahsedilmektedir (Rahman vd., 2015: 190). Üçüncü boyut olan etkileşimsel adalet algısı ise, çalışanın örgütteki prosedürler uygulanırken yöneticinin kendisine yönelik olan tutumunu ve davranışlarını değerlendirmesidir. Yöneticisinin çalışanlarına yönelik dürüst, hakkaniyetli, adil ve samimi davranışlar sergilemesi beklentisini vurgulayan çalışanın karşılaştığı saygılı davranış ve olumlu anlamda onura vurgu yapması ya da maruz kaldığı olumsuz ve kabul görmeyecek durumlara karşı değerlendirme yapmasıdır (Castillo ve Fernandez, 2017: 287).

Dağıtımsal adalet algısı ile etkileşimsel adalet algısı arasında nispeten bir köprü görevi gören prosedürel adalet algısı, tutarlı olma, önyargıdan uzak durma, doğru olma, düzeltilebilir olma, temsil gücüne sahip olma ve etik olma gibi bazı özelliklere de sahiptir (Cropanzano vd., 2007; İçerli, 2010: 82). Kazanımlar ve bunların kazanılma sürecinin aynı sonuç gibi değerlendiriliyor olmasından dolayı dağıtım adaleti algısıyla oluşan yüksek korelasyon (Folger, 1987; Sweeney ve McFarlin 1997; Welbourne vd., 1995; Martocchio ve Judge 1995; Cropanzano ve Ambrose 2001; Colquitt, 2001) ve etik liderliğin süreçle çok daha fazla alakadar olması nedeniyle, örgütsel adalet algısının yalnızca prosedürel adalet algısı boyutu çalışma kapsamında incelenmiştir. İşlemsel adalet algısı olarak da anılan prosedürel adalet algısı, her ne kadar ideali anlatıyor olsa da içerdiği tüm işlemler, süreçler ve uygulamalar bireylerin algılama yapısına ve yeterliliğine göre şekillenir. Başka bir ifadeyle, örgüt içinde alınacak bir karar esnasında bireylerarası ilişkilerin yapısına ve niteliğine, prosedürlerin neler olduğuna ilişkin bilgilendirmelerin ve açılamaların yapılıp yapılmadığına ilişkin özellikle bakılmalıdır. Kazanımlar ve bunların kazanılma sürecinin aynı sonuç gibi değerlendiriliyor olmasından dolayı dağıtım adaleti algısıyla oluşan yüksek korelasyon (Folger, 1987; Sweeney ve McFarlin 1997; Welbourne vd., 1995; Martocchio ve Judge 1995; Cropanzano ve Ambrose 2001; Colquitt, 2001) ve etik liderliğin süreçle çok daha fazla alakadar olması nedeniyle, örgütsel adalet algısının yalnızca prosedürel adalet algısı boyutu çalışma kapsamında incelenmiştir.

\subsection{Etik Liderlik}

Liderlik, yalnızca yönetim ve idari işlerde değil yaşamın hemen hemen her alanında kendini göstermektedir. Tarihsel süreç içerisinde de durum, kültürel yapı ve koşullara bağlı kalarak evirilmiştir. Çünkü, özellikle de günümüz toplumsal yapısı ve işleyişi açık birer sistem içerisinde sürekliliği olan bir rekabet ortamında yer almaktadır. Böyle olunca da çalışanlar için mutlaka bir yönlendirici güce duyulan ihtiyaç kaçınılmaz hale gelmektedir (Hodgetts ve Luthans, 2003).

Toplumun sosyo-ekonomik, kültürel ve siyasal konumlanmasıyla doğrudan ilişki içerisinde olan etik, belirlenmiş veya sınıflandırılmış belli başlı davranış kalıpları içerisinde ifade edilemeyecek kadar kapsamlıdır (Sezgül, 2010: 241). Örgütlerde tıpkı bir pusula görevi gören etik, gidilecek yönü tarif etmekten öte gidilen yerin yönünün durumunu da ifade etmektedir. Bu durumda da etik, bireyin davranışlarının doğru olup olmadığını kontrol etmesi için önemli bir niteliğe de sahiptir (Akıllı, vd., 2013: 27). Yapılan pusula 


\section{S. Aksoy Kürü 12/4 (2020) 3895-3913}

benzetmesindeki etik kavramını bir örgüt içinde içselleştirip çalışanlara doğru yolu gösterecek olan etik lider ise, Brown ve arkadaşlarının (2005: 120) yaptı̆̆ "kişisel faaliyetlerinde ve kişilerarası ilişkilerde normatif uygunluk çerçevesinde yönetim sergileyen ve bu tarz yönlendirmeleri iki yönlü iletişim, güçlendirme ve ahlaki düşünmeye yönelterek artırmayı hedefleyen bir liderlik tarzıdır." tanımlamayla ortaya konmaktadır. Sosyal bilimlerde uygulamalı araştırma sayısı gün geçtikçe artan etik liderlik, bazı temel özelliklere sahiptir. Harvey'in (2004: 23) siralamasına göre bu özellikler;

-Çalışma ortamında, işin yapılması sürecinde ilke ve etik standartları ifade etmesi ve bunların anlaşılabilir olması ve uygulanması için çalışanlara yardım etmesi,

-Astlarını etik davranmaları için sorumlu tutarak etik değerlerin ihlal edilmesi durumunda hoşgörülü davranmaması,

- Etrafındakilere etik davranışlar hususunda rol model olması,

-Karar süreçlerinde etik değerlere sıkı sıkıya bağlı olması ve alınan kararların sonuçlarını da etik anlamda sorgulaması,

-Çalışma ortamındaki kuralları ve politikaları etik temellere dayandırması,

-Etrafındaki bireylerin (iş dışındakiler) etik ve doğru davranışlar edinmesine yardım etmesi,

-Kurumsal gelişmeyi sürdürebilir şekilde yapabilmesi,

-Astları arasında görevlendirmeler yaparken önceliği mutlaka etik davranışa sahip çalışanlara vermesi,

-Çalışma ortamında etik davranış bilincinin yer etmesi için çalışanlara liderlik ederek yol göstermesidir (Yilmaz, 2006: 33).

İfadelerden de anlaşılacağı üzere etik liderlik, bir rol model olmanın ötesinde yapıcı ve kazanım sağlayıcı bir rol model niteliklerine de sahiptir. Yalnızca çalışma hayatında değil aynı zamanda da özel hayatında da etik değerleri gözeterek hareket eden bir yapıdadır. Mutlaka en doğrunun ne olduğu ve egoizmden uzak; çoğunluğun faydasını gözeten davranışlar sergileyen etik liderler, karar alırken astlarından görüş almayı bir zenginlik olarak kabul eder (Brown vd., 2005: 134).

\section{3. Örgütsel Özdeşleşme}

İnsanlar, bireysel olarak kendilerini tek ve eşsiz birer varlık olarak kabul etmektedir. En baştan itibaren "ben kimim?" sorusuna doğru bir cevap bulma gayreti güden birey için çevreye dönük bir yönelim vardır. İnsanın sosyal bir varlık olması nedeniyle mutlaka biri veya birilerine ihtiyaç duyması kaçınılmazdır. Dolayısıyla da kendini ait hissettiği bir grubun varlığı da onu öteki gruplardan ayrıştırmaktadır. Birey tarafından grup üzerinden yapılan bu ayrıştırma şüphesiz ki farklı değişkenlerin ortaya çıkmasına sebep olmaktadır. Bireyin özel yaşantısında yaptı̆̆ bu ayrıştırmaya dayalı sınıflandırmanın örgütsel düzeyde yapılıyor olmasıyla ve bireyin kendisini hem mesleki hem de örgütsel anlamda içinde yer aldığı örgütün ayrılmaz bir parçası olarak hissederek aidiyetini tanımlayan örgütsel özdeşleşmeyi ortaya çıarmaktadır (Van Dick vd., 2004: 172). Hall ve arkadaşlarının (1970: 177) belirttiği üzere, yüksek düzeyde bir bağlllık ve hatta adanmışlığı içeren özdeşleşme, bireyin sahip olduğu kimlikle örgütün kimliğinin ve değerlerinin aynı olması gerekliliğini öne çıarmaktadır. Örgütsel özdeşleşmenin Sosyal Kimlik Kuramı'na (Tajfel, 1978; Turner ve Tajfel, 1986) atfedilerek sosyal özdeşleşmenin bir uzantısı olduğu ifade edilebilir. Bireyin örgütüne yönelik olarak geliştirdiği benlik, tutum ve davranışlarının temelini oluşturması bakımından da önem taşımaktadır (İşcan, 2006: 162). Nitekim, bireyle örgüt arasındaki psikolojik bir birleşmeyi ve bütünlük kurmayı ifade eden örgütsel özdeşleşme, bireyin motivasyonunu artıran nitelikteki grup değerlerini, amaçlarını ve ilgilerini bireyin değerleriyle aynı olarak algılamasına imkân vermektedir (Van Knippenberg, 2000: 360). Sıradan bir iş birliğinin çok ötesinde olan örgütsel özdeşleşme, bireylerin çalışma ortamında birlik içinde olmalarına imkân sağlayan duyguları, düşünceleri, değerleri ve kararları paylaşma şansını doğuran bir tür ortaklık duygusudur (Gossett, 2002). Bu durumda özdeşleşmeyi, neticesinde değerli bir ürüne dönüşen bir süreç olarak kabul etmek doğru olmaktadır (Cheney, 1983: 344).

Biz olma düşüncesinin hâkim olduğu ve adeta bir ailenin mensubu olmayı ifade eden örgütsel özdeşleşme, Riketta'nın (2005: 360) da belirttiği haliyle, çalışanlardaki örgütlere ait olma hissi, bağlılık duyma ya da genel anlamda benlik tanımlanması sırasında bireyin kendini belli bir örgütün üyesi olarak algılama sürecidir ifadesiyle de benzer anlamı içermektedir. Benzer şekilde, Rousseau'ya (1998: 217) göre de örgütsel özdeşleşme, bir departman ya da iş grubuna karşı bireyin kendisini aidiyet ve sadakat içinde algılama sürecidir. Özdeşleşmenin temel noktasındaki unsur olan, bireyin örgütle aynı duygulara sahip olması 


\section{S. Aksoy Kürü 12/4 (2020) 3895-3913}

düşüncesi, birlikte hareket etme ve nitelikli kararlar alabilmede etkilidir (Ashforth vd., 2008: 328). Çünkü benlik tanımlaması yapılırken oluşturulan birlik yapısıyla hareket edilmektedir. Güçlü bir bağlılığı ifade eden bu benlik yapısı, örgüt üyelerinin bütünleşmesi ve uyumluluk göstermesi için kilit noktadır (Katrinli vd., 2008: 356). Nitekim, örgütsel özdeşleşme için bireyin örgütüne yönelik olan en geniş perspektiften olumlu duygu durumlarını ölçme gayretidir (Mael ve Ashforth, 1995: 312) demek de mümkündür.

\subsection{Kavramlar Arasındaki İlişkiler}

Örgüt içinde algılanan durumların, geliştirilen tutumların ve nihayetinde sergilenen davranışların mutlaka bazı öncülleri vardır. Çalışanların örgüt içindeki davranışlarının veya alışkanlıklarının bir öncülü de örgütsel adalet algisıdır (McFarlin ve Sweeney, 1992: 626-637). Örgütsel adalet algisının bir alt boyutu olarak ele alınan prosedürel adalet algısı, bireylerin kararlara katılım gösterebilmesine imkân vermesi sayesinde çalışanda motivasyon artışını sağlayarak bireyin kendisini tıpkı bir ailenin üyesi olarak hissetmesine imkân vermektedir (Thibaut ve Walker, 1975, 1978; Leventhal, 1980). Çünkü, örgütteki işlerin ilerlemesinde izlenen prosedürlerin ne denli tatmin edici olduğu, o örgütte lidere olan inancın ve güvenin artmasını sağlamaktadır ve bu sayede de örgüte bağlllık ve özdeşleşme artış görülebilmektedir (DeConinck ve Stilwell, 2004: 225-231). Benzer bir ifadeyle prosedürel adalet algısı, çalışanların örgüt içindeki prosedürle alakalı olarak bilgi sahibi olmaları, kararlara katılımlarına imkân verilmesi ve kendilerinin sürecin bir unsuru olduklarının bilinmesi halinde adil bir ortamın olduğunu benimsetmektedir demek de mümkündür. Bu sayede de çalışanların ahlaki ve hakkaniyet düzeyi yüksek adaletli bir çalışma ortamında oldukları düşünerek örgüte yönelik sadakat duyguları gelişecektir. Gelişen bu duygularla da çalışanların örgütle bağlılık ve örgütle özdeşleşme içine girmeleri sağlanacaktır (Folger,1989: 155; Tang vd.,1996: 3; Cropanzano vd., 2007: 38).

Çalışanla örgütü arasında oluşacak bağın önemli bir unsuru da liderin varlığı ve bu liderin davranış yapısıdır. Liderin yol gösterici ve çalışanlar için bir modeli temsil etmesinin ötesinde örgüt içindeki diğer unsurlarla da bütünlük içinde de olması beklenir. Önleyici tedbirler ve iyileştirmeye yönelik uygulamaları sayesinde etik liderliğin bu bütünlüğü sağlayacak bir yapıda olduğu düşünülmektedir. Nitekim, etik liderlik, örgüt içerisinde doğru olanın ne olduğuna yönelik yaptığı kılavuzluğu (Mayer vd., 2010: 8) sayesinde etik olmayan davranışların ortaya çıkmasını engellemektedir (Elçi, vd. 2012: 288). Örgütlerde etik liderlerin davranışlarının, çalışanların gözünde rol model konumunda olduğu bilgisine bağlı kalınarak, lideriyle uyum yakalayan bir çalışanın örgütsel anlamda da uyum yakalaması öngörülmektedir (Grojean vd., 2004: 229). Bilişsel anlamda sağlanacak bu uyum devamında bağlllığı ve nihayetinde de örgütle yaşanacak özdeşleşmeyi beraberinde getirecektir (Sluss ve Ashforth, 2008: 812). Etik liderler, çalışanların örgütleriyle bütünleşmesinde ve biz olmalarında sorumluluk sahibidirler. Çünkü hem kararlara katılım göstermelerinde hem de iletişimde açık olmaları sayesinde örgüt değerlerinin içselleştirilmesi ve ailenin bir üyesi oldukları bilincini çalışanlarına aktarabilmektedirler.

Gerek örgüt tarafından gerekse yönetici (lider) tarafından sergilenen davranışlarda adil ve şeffaf olunması halinde çalışanların gözünde örgütün imajı olumlu yönde olacaktır. Bu da çalışanların örgütleriyle özdeşleşmelerine yol açacaktır (Lipponen vd., 2004: 395). Hem liderin hem de örgütteki prosedürlerin tanıdığı serbesti alanı sayesinde çalışanlarda, örgütün onlara saygı duyup değer veriyor düşüncesi oluşacaktır. Oluşan bu düşünce de örgütün üyesi olmalarında onları isteklendirecektir ve örgütleriyle gurur duymalarını sağlayacaktır (Olkkonen ve Lipponen, 2006: 204-205). Oluşan örgüt üyeliğiyle, bireyin artık kendini ifade ederken kullandığı gurur verici kelimeleri örgütü için de kullanıyor olmaya evrilecektir. Bu da örgüte uzun vadede önemli kazanımlar sağlayarak örgütsel özdeşleşmeyi kalıcı kılacaktır (İşcan, 2006: 161).

\section{YÖNTEM}

\subsection{Araştırmanın Evren ve Örneklemi}

Araştırmada, İstanbul İl Milli Eğitim Müdürlüğü'nün güncel bilgilerine bağlı olarak 2018-2019 eğitim öğretim yılında İstanbul ili Kadıköy, Maltepe, Ataşehir, Üsküdar ilçelerinde eğitim vermekte olan 417 devlet okulu araştırmanın evrenini oluşturmaktadır. Bu okullarda çalışmakta olan toplamda 14.762 öğretmen bulunmaktadır. Araştırmaya sadece devlet okullarındaki öğretmenlerin dahil edilmesinin sebebi, özel okulların araştırmaya dahil olmada gösterdikleri isteksizlikler ve araştırma modelindeki değişkenlerin özel okullara nazaran devlet okullarının daha sıkı kurallar ve prosedürleri bünyesinde barındırmalarından da kaynaklanmaktadır. Araştırmanın örneklem büyüklüğünü hesaplamak üzere aşağıdaki örneklem büyüklüğü 
eşitliği kullanılmıştır.

$\mathrm{n}=\mathrm{n}_{0} /\left(1+\mathrm{n}_{0} / \mathrm{N}\right), \quad \mathrm{n}_{0}=\left(\mathrm{t}^{2} \times \mathrm{s}^{2}\right) / \mathrm{d}^{2}$

Formüllerdeki N: evren büyüklüğü, n: örneklem büyüklüğü, t: güven düzeyine karş1lık gelen tablo z değeri ( 0,05 için $1,96,0,01$ için 2,58 ve 0,001 için 3,28$)$, s: evren için tahmin edilen standart sapma ve d: kabul sapma toleransinı ifade etmektedir (Bartlett vd., 2001: 43).

$\mathrm{n}_{\mathrm{o}}=\left(1,96^{2} \times 0,5^{2}\right) / 0,05^{2}=384,16 \mathrm{n}=384,16 /(1+384,16 / 14762)=374,42$

Araştırma evreninin 14.762 olduğu bilgisine dayanarak kullanılan eşitlikle hesaplanan değerin 374 olduğu görülmektedir. Araştırma kapsamında hazırlanmış olan anket formları İstanbul İl Millî Eğitim Müdürlüğü'nden alınan izinler doğrultusunda araştırmacı tarafından her bir öğretmene kapalı zarf içinde verilmek şartıyla toplamda 800 tane anket formu teslim edilmiştir. Araştırmaya katılım gönüllülük esasına bağlı olduğu için öğretmenlerin doldurduğu anket formları araştırmacı tarafından teslim alınmıştır. Teslim alınmış olan anket formlarının toplamı 763 olup değerlendirmeye dahil edilen anket formu ise 721 tanedir. Bu durumda anket formlarının \%94'ü analiz için uygun olarak kabul edilmiştir. Balcı'nın (2004) da belirttiği gibi \%94'lük oran istatistiksel olarak anlamlı bir yargıya erişebilmek için gerekli olan \%80 değerinin üstündedir.

Araştırma kapsamında toplanmış olan nicel veriler için uç değerler temizlenerek basıklık ve çarpıklık değerleri kontrol edilmiş ve normallik varsayımı incelenmiştir. Analize elverişli hale getirilen veriler için öncelikle geçerlik ve güvenirlik analizleri yapılmıştır. Araştırmada kullanılan ölçeklerin yapı geçerliklerini tespit edebilmek amacıyla SPSS programı yardımıyla açımlayıcı faktör analizi (AFA) (Büyüköztürk, vd., 2012) yapılırken, YEM-AMOS programı yardımıyla da doğrulayıcı faktör analizi (DFA) (Byrne, 2010) yapılmıştır. Ölçeklerin güvenirliliklerini belirlemek amacıyla her bir ölçeğin Cronbach's Alpha katsayıları hesaplanmıştır. Her bir ölçek için geçerlik ve güvenirlik düzeyleri elde edildikten sonra gizil (örtük) değişkenler arasına kovaryans yolları tanımlanıp bir ölçüm modeli geliştirilmiştir. Geliştirilen ölçüm modelinde elde edilen iyi uyum indekslerinden sonra kovaryanslar silinerek yapısal modeli oluşturmak amacıyla gizil değişkenlerin arasına tek yönlü yollar tanımlanmıştır (Bayram, 2016).

Araştırma için geleneksel yöntemlere kıyasla daha fazla kabul gören ve nispeten daha iyi sonuçlar veren, öncelikle belli bir kuramsal çerçeveye dayandırılarak gözlemlenen veya gözlemlenemeyen değişkenler arasındaki doğrudan veya dolaylı etkileri yalnızca tek bir model üzerinde inceleyerek test edebilen bir istatistik yöntemi olan yapısal eşitlik modellemesi (YEM) tercih edilmiştir (Bayram, 2016; Byrne, 2010; Çelik ve Yılmaz, 2016). Kurulan YEM modelinin analiz edilebilmesi amacıyla da güvenilir ve güçlü çözüm olanakları sunan AMOS yazılımı (Meydan ve Şeşen, 2015) tercih edilmiştir.

\subsection{Veri Toplama Araçları}

Araştırmanın verisi, daha önceki araştırmacılar tarafından geçerliliği ve güvenirliliği doğrulanmış ölçekler vasıtasıyla toplanmıştır. Veri toplama aracı olarak örneklemi oluşturan öğretmenlere sunulan ölçekler “Örgütsel Adalet Algısı Ölçeği” (Colquitt, 2001), “Etik Liderlik Ölçeği”" (Brown vd., 2005: 131) ve “Örgütsel Özdeşleşme Ölçeği" (Mael ve Ashforth, 1992: 110) kullanılmıştır. Tüm ölçeklerde birden fazla ifade (madde) kullanılmış olup katılımcıların bu ifadelere birden beşe kadar bir değer atamasında 5'li Likert tipi eşit aralıklı ölçekleme kullanılmıştır. Bu araştırmada uygulanan anket formlarındaki ifadelerin cevaplandırılmasında kullanılan 5'li Likert ölçeğinde 1=Kesinlikle Katılmıyorum, 2=Katılmıyorum, 3=Kararsızım, 4=Katılıyorum ve $5=$ Kesinlikle Katılıyorumu temsil etmektedir. Kullanılan ölçeklere ilişkin tanımlayıcı bilgilere aşağıda yer verilmiştir.

\subsubsection{Prosedürel adalet algısı ölçeği}

Prosedürel adalet algısı ölçeği, Colquitt (2001) tarafından geliştirilen ve Türkçe uyarlaması Özmen vd. (2007) tarafından yapılmış olan, “Ücret, terfi, ödül vb.'nin verildiği süreçler ile elde edilen kazanımlar üzerinde etkim oldu." ve “Ücret, terfi, ödül vb.'nin verildiği süreçleri doğru bilgiye dayalı buluyorum.” gibi ifadelerin de yer aldığı toplam yirmi ifadeden oluşan dört boyutlu örgütsel adalet algisı ölçeğinin bir alt boyutunu içermektedir. Orijinal ölçeğin Cronbach's Alpha Güvenirlik Katsayısı $(\alpha), 0,866$ 'dır. 


\subsubsection{Etik liderlik ölçeği}

Etik liderlik ölçeği, Brown vd. (2005: 131) tarafından geliştirilen ve Türkçe uyarlaması Tuna vd. (2012) tarafından yapılmış olan, "Okul müdürüm karar alırken "yapılacak en doğru şey nedir" diye sorar." ve "Okul müdürüm etik standartları çiğneyen iş görenleri yaptırım uygular; disipline eder." gibi benzeri ifadelerin yer aldığı toplam 10 ifadeli ve tek boyutludur. Orijinal ölçeğin Cronbach's Alpha Güvenirlik Katsayısı $(\alpha)$, $0,920^{\prime}$ dir.

\subsection{3. Örgütsel özdeşleşme ölçeği}

Örgütsel özdeşleşme ölçeği, Mael ve Ashforth (1992: 110) tarafından geliştirilen ve Türkçe uyarlaması Tak ve Aydemir (2004) tarafından yapılmış olan, "Başka biri çalıştı̆̆ım okuldan övgüyle bahsettiğinde, bunu şahsıma yönelik yapılmış bir övgü, iltifat olarak kabul ederim." ve "Çalıştığım okulun başarılarını kişisel başarım olarak kabul ederim." gibi benzeri ifadelerin yer aldığı toplam altı ifadeli ve tek boyutludur. Orijinal ölçeğin Cronbach's Alpha Güvenirlik Katsayısı $(\alpha)$, 0,870'dir.

\subsection{Araştırmanın Amacı ve Hipotezleri}

$\mathrm{Bu}$ araştırmanın temel motivasyonu öğretmenlerin prosedürel adalet algıları ile örgütsel özdeşleşmeleri arasındaki ilişkide etik liderlik uygulamalarının aracılık rolünü belirlemektir. Bu bağlamda da incelenmek üzere aşağıdaki diğer üç hipotez de ele alınmaktadır.

$\mathrm{H}_{1}$ : Öğretmenlerin prosedürel adalet algılamalarının, örgütsel özdeşleşmeleri üzerinde etkisi vardır.

$\mathrm{H}_{2}$ : Öğretmenlerin etik liderlik algılamalarının, örgütsel özdeşleşmeleri üzerinde etkisi vardır.

$\mathrm{H}_{3}$ : Öğretmenlerin prosedürel adalet algılamalarının, etik liderlik algılamaları üzerinde etkisi vardır.

$\mathrm{H}_{4}$ : Öğretmenlerin prosedürel adalet algılamalarının, örgütsel özdeşleşmeleri üzerindeki etkisinde etik liderlik algılamalarının aracılık rolü vardır.

\subsection{Araştırmanın Modeli}

Yapılan bu araştırmada birden çok değişkenin birbiriyle olan olası ilişkisinin tespiti için hazırlanmış olan anket formları yardımıyla çalışıldığı ilişkisel bir tarama modeli kullanılmıştır (Karasar, 2012; Büyüköztürk vd., 2012). İlgili modeli oluşturmak amacıyla örgütsel adalet algısı ölçeğinde yer alan prosedürel adalet algısı ölçeği, etik liderlik ölçeği ve örgütsel özdeşleşme ölçeği kullanılmıştır. Araştırmanın temel amacına ve belirlenmiş olan dört hipoteze uygun olarak geliştirilen araştırmanın kavramsal modeli ise aşağıda (Bkz.: Şekil 1) yer almaktadır. Bu modele göre, mevcut iki değişken arasındaki ilişkinin yeni bir değişken olarak modele dahil edilen değişken tarafından oluşturulduğu durum olarak açıklanabilen aracılık rolünün tespitine yönelik bir model olduğu anlaşılmaktadır (Arı vd., 2010: 155). Bu ilişkiler çerçevesinde hazırlanan modelde prosedürel adalet algısı (bağımsız değişken), etik liderlik (aracı değişken) ve örgütsel özdeşleşme (bağımlı değişken) değişkenler olarak incelenmiştir.

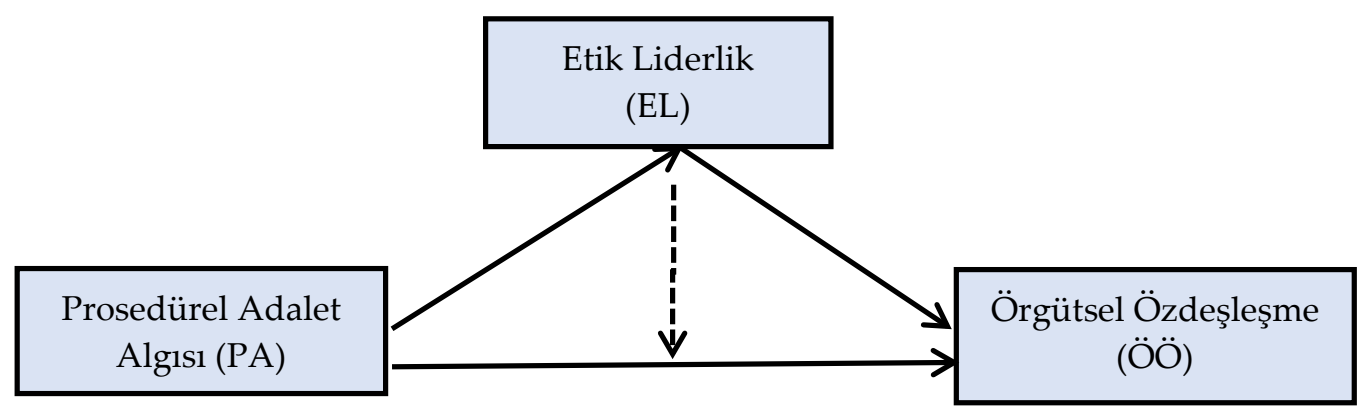

Şekil 1. Araştırmanın Kavramsal Modeli 


\section{BULGULAR}

\subsection{Demografik Özelliklere İlişkin Bulgular}

Araştırmaya dahil edilen örneklemin ( $\mathrm{n}=721$ ) yaş, medeni durum, cinsiyet, eğitim seviyesi ve okuldaki hizmet süresini içeren demografik özelliklere ilişkin duruma Tablo 1'de yer verilmiştir.

Tablo 1- Örneklemi oluşturan öğretmenlerin demografik özellikleri $(n=721)$

\begin{tabular}{lccc}
\hline \multirow{2}{*}{ Değişken } & $\begin{array}{c}\text { Değişkenin } \\
\text { Alt Kategorileri }\end{array}$ & Frekans (n) & Yüzde (\%) \\
\hline \multirow{2}{*}{ Cinsiyet } & Kadın & 486 & 67,4 \\
& Erkek & 235 & 32,6 \\
\hline \multirow{2}{*}{ Medeni Hal } & Evli & 474 & 65,7 \\
& Bekar & 247 & 34,3 \\
\hline \multirow{3}{*}{ Yaş } & $18-29$ yaş & 196 & 27,2 \\
& $30-39$ yaş & 321 & 44,5 \\
& $40-49$ yaş & 142 & 19,7 \\
\multirow{3}{*}{ Eğitim Seviyesi } & $50-59$ yaş & 52 & 7,2 \\
& 60 yaş ve üzeri & 10 & 1,4 \\
\hline \multirow{3}{*}{ Şu an Çalışılan Okuldaki } & Üniversite & 560 & 77,7 \\
Toplam Hizmet Süresi & Yüksek Lisans & 160 & 22,2 \\
& Doktora & 1 & 0,1 \\
\hline & 1 ylldan az & 346 & 17,8 \\
& $1-5$ yıl & 39 & 48 \\
& $6-10$ yıl & 155 & 5,4 \\
& $11-15$ yll & 38 & 21,5 \\
\hline
\end{tabular}

Tablo 1'e bakıldığında, araştırmaya katılım gösteren öğretmenlerin \%67,4'ü kadın (n=486), \%32,6'sı (n=235) erkektir. 721 öğretmenin \%65,7'si evli (n=474) iken \%34,3'ünün bekâr olduğu görülmektedir. Öğretmenlerin $\% 44,5^{\prime}$ inin yaş aralığ $130-39$ yaş aralığındadır; \%77,7'si (n=560) üniversite mezunudur ve meslekte en fazla bulundukları görev süresi aralığı ise \%48 ile 1-5 yıl aralığı olarak bulgulanmıştır.

\subsection{Değişkenlerle İlgili Betimsel Analizler ve Korelasyon Matrisi}

Araştırmaya katılım gösteren öğretmenlerin anket formundaki ölçeklerde yer alan ifadelere verdikleri cevapların aritmetik ortalamaları ve standart sapmaları ile değişkenler arasındaki ilişkinin düzeyini ve yönünü gösteren korelasyon katsayılarına Tablo 2' de yer verilmektedir.

Tablo 2. Tanımlayıcı İstatistikler ve Korelasyon Analizi (n: 721)

\begin{tabular}{|l|c|c|c|c|c|c|c|}
\hline Değişken & Ortalama & $\begin{array}{c}\text { En } \\
\text { Küçük }\end{array}$ & $\begin{array}{c}\text { En } \\
\text { Büyük }\end{array}$ & $\begin{array}{c}\text { Standart } \\
\text { Sapma }\end{array}$ & PA & EL & ÖÖ \\
\hline 1. PA & 3,05 & 2,85 & 3,26 & 0,888 & $0,889^{\alpha}$ & & \\
\hline 2. EL & 3,52 & 3,28 & 3,74 & 0,858 & $0,516^{* *}$ & $0,936^{\alpha}$ & \\
\hline 3. ÖÖ & 3,40 & 3,08 & 3,74 & 0,925 & $0,295^{* *}$ & $0,431^{* *}$ & $0,874^{\alpha}$ \\
\hline
\end{tabular}

${ }^{* *}$ Korelasyon 0,01 düzeyinde anlamlıdır. $\left.{ }^{* *} p<0,01\right)$ a: Değişkenin içsel güvenirlik katsayı (Cronbach's alpha). PA: Prosedürel adalet algısı, EL: Etik liderlik, ÖÖ: Örgütsel özdeşleşme

Tablo 2'ye göre; değişkenlerin 0,01 düzeyinde anlamlı ilişkiler içinde olduğu anlaşılmaktadır. Araştırmaya katılan öğretmenlerin örgütsel adalet algısının bir alt boyutu olan prosedürel adalet algısı "Kararsızım (3)", yöneticilerini etik birer lider olarak değerlendirmelerinin "Katılıyorum (4)" ve son değişken olan örgütsel özdeşleşmenin "Katılmıyorum (3)" düzeyinde olduğu görülmektedir. Korelasyon tablosundaki ilişkilerde ise, prosedürel adalet algısının genel ortalaması; etik liderlik değişkeniyle pozitif korelasyon $(r=0,516$, 


\section{S. Aksoy Kürü 12/4 (2020) 3895-3913}

$p<0,01)$, benzer şekilde örgütsel özdeşleşme ile de pozitif korelasyon $(r=0,295, p<0,01)$ içinde olduğu anlaşılmaktadır. Bunların yanı sıra, araştırmaya katılan öğretmenlerin etik liderlik algısının örgütsel özdeşleşmeyle pozitif korelasyon $(\mathrm{r}=0,431, \mathrm{p}<0,01)$ içinde olduğu da görülmektedir. Prosedürel adalet algısının etik liderlik ile orta düzeyde, örgütsel özdeşleşme ile orta-düşük düzeyde ilişkili olduğu; etik liderliğin ise örgütsel özdeşleşmeyle orta düzeyde ilişki içerisinde olduğu tespit edilmiştir.

\subsection{Faktör Analizleri}

Anket formundaki ifadeler için yapılmış olan açımlayıcı faktör analizi sonuçları aşağıda yer alan Tablo 3'te verilmiştir.

Tablo 3. Açımlayıcı Faktör Analizi ve Doğrulayıcı Faktör Analizi Sonuçları

\begin{tabular}{|c|c|c|c|c|}
\hline \multicolumn{2}{|l|}{ Ölçek maddeleri } & \multicolumn{3}{|c|}{$\begin{array}{c}\text { Açımlayıcı Faktör } \\
\text { Analizi Faktör Yükleri }\end{array}$} \\
\hline \multicolumn{5}{|l|}{ Prosedürel Adalet Algısı (PA) } \\
\hline \multicolumn{2}{|c|}{ PA5. "Ücret, terfi, ödül vb. verildiği süreçleri doğru bilgiye dayalı buluyorum." } & 0,853 & - & - \\
\hline \multicolumn{2}{|c|}{$\begin{array}{l}\text { PA4. "Ücret, terfi, ödül vb. verildiği süreçler önyargilardan uzak } \\
\text { uygulanabiliyor." }\end{array}$} & 0,827 & - & - \\
\hline \multicolumn{2}{|c|}{$\begin{array}{l}\text { PA7. "Ücret, terfi, ödül vb. verildiği süreçler etik ve ahlaki standartlara } \\
\text { uygundur." }\end{array}$} & 0,824 & - & - \\
\hline \multicolumn{2}{|c|}{$\begin{array}{l}\text { PA2. "Ücret, terfi, ödül vb. verildiği süreçler ile elde edilen kazanımlar üzerinde } \\
\text { etkim oldu." }\end{array}$} & 0,735 & - & - \\
\hline \multicolumn{2}{|c|}{$\begin{array}{l}\text { PA1. "Ücret, terfi, ödül vb. verildiği süreçler sırasında görüş ve duygularımı } \\
\text { ifade etmem mümkündür." }\end{array}$} & 0,733 & - & - \\
\hline \multicolumn{2}{|c|}{ PA3. “Ücret, terfi, ödül vb. verildiği süreçler sürekli uygulanıyor.” } & 0,727 & - & - \\
\hline \multicolumn{2}{|c|}{$\begin{array}{l}\text { PA6. "Ücret, terfi, ödül vb. verildiği süreçler sonucu elde edilen kazanımlara } \\
\text { itiraz edebiliyorum." }\end{array}$} & 0,726 & - & - \\
\hline Cronbach Alpha $(\alpha)$ & \multicolumn{4}{|l|}{0,889} \\
\hline Açıklanan Toplam Varyans & \multicolumn{4}{|l|}{$\% 60,365$} \\
\hline KMO & \multicolumn{4}{|l|}{0,888} \\
\hline Bartlett's Testi/df & \multicolumn{4}{|l|}{$2638,314 / 21$} \\
\hline DFA Uyum İndeksleri & \multicolumn{4}{|c|}{$\begin{array}{l}\chi^{2}=26,283, \quad \mathrm{sd}=10, \quad \chi^{2} / \mathrm{sd}=2,628, \quad \mathrm{p}=0,000, \quad \mathrm{CFI}=0,994, \mathrm{GFI}=0,990, \\
\mathrm{NFI}=0,990, \mathrm{RMR}=0,029, \mathrm{RMSEA}=0,048, \mathrm{AGFI}=0,971\end{array}$} \\
\hline \multicolumn{5}{|l|}{ Etik Liderlik (EL) } \\
\hline \multicolumn{2}{|c|}{$\begin{array}{l}\text { EL8. "Okul müdürüm etik anlamında işlerin nasıl doğru yapılacağıyla ilgili } \\
\text { örnek teşkil eder." }\end{array}$} & - & 0,895 & \\
\hline \multicolumn{2}{|c|}{ EL9. “Okul müdürüm çalışanların fikirleriyle yakından ilgilenirler.” } & - & 0,885 & - \\
\hline \multicolumn{2}{|c|}{ EL5. “Okul müdürüm adil ve dengeli kararlar verir." } & - & 0,878 & - \\
\hline \multicolumn{2}{|c|}{ EL7. “Okul müdürüm iş görenlerle iş etiği ve değerleri hakkında görüşür.” } & - & 0,871 & - \\
\hline \multicolumn{2}{|c|}{ EL6. “Okul müdürüm güvenilebilir bir kişidir.” } & - & 0,864 & \\
\hline \multicolumn{2}{|c|}{$\begin{array}{l}\text { EL10. "Okul müdürüm başarıyı sadece sonuçlarla değil aynı zamanda hangi } \\
\text { yollarla elde edildiğiyle de değerlendirir." }\end{array}$} & - & 0,846 & - \\
\hline \multicolumn{2}{|c|}{ EL2. "Okul müdürüm karar alırken "yapılacak en doğru şey nedir" diye sorar." } & - & 0,833 & - \\
\hline \multicolumn{2}{|c|}{$\begin{array}{l}\text { EL1. “Okul müdürüm kişisel yaşamını etik davranış üzerine kurar ve bu şekilde } \\
\text { sürdürür.” }\end{array}$} & - & 0,734 & - \\
\hline \multicolumn{2}{|c|}{$\begin{array}{l}\text { EL4. "Okul müdürüm etik standartları çiğneyen iş görenleri yaptırım uygular; } \\
\text { disipline eder." }\end{array}$} & - & 0,591 & \\
\hline \multicolumn{2}{|c|}{$\begin{array}{l}\text { EL3. "Okul müdürüm iş görenlerin ne söyleyeceklerini dinler, iş görenlerin } \\
\text { önerilerini dikkate alır." }\end{array}$} & - & 0,565 & - \\
\hline Cronbach Alpha $(\alpha)$ & \multicolumn{4}{|l|}{0,936} \\
\hline Açıklanan Toplam Varyans & \multicolumn{4}{|l|}{$\% 64,764$} \\
\hline KMO & \multicolumn{4}{|l|}{0,950} \\
\hline Bartlett's Testi/df & \multicolumn{4}{|l|}{$5548,853 / 45$} \\
\hline
\end{tabular}




\begin{tabular}{|c|c|c|c|c|}
\hline DFA Uyum İndeksleri & \multicolumn{4}{|c|}{$\begin{array}{l}\chi^{2}=80,423, \mathrm{sd}=29, \chi^{2} / \mathrm{sd}=2,773, \mathrm{p}=0,000, \mathrm{CFI}=0,991, \mathrm{GFI}=0,978, \\
\mathrm{NFI}=0,986, \mathrm{RMR}=0,020, \mathrm{RMSEA}=0,050, \mathrm{AGFI}=0,959\end{array}$} \\
\hline \multicolumn{5}{|l|}{ Örgütsel Özdeşleşme (ÖÖ) } \\
\hline \multicolumn{2}{|c|}{$\begin{array}{l}\text { ÖÖ5. "Başka biri çalıştı̆̆ım okuldan övgüyle bahsettiğinde, bunu şahsıma } \\
\text { yönelik yapılmış bir övgü, iltifat olarak kabul ederim." }\end{array}$} & - & - & 0,846 \\
\hline \multicolumn{2}{|c|}{ ÖÖ4. "Çalıştığım okulun başarılarını kişisel başarım olarak kabul ederim." } & - & - & 0,824 \\
\hline \multicolumn{2}{|c|}{$\begin{array}{l}\text { ÖÖ1. “Başka biri çalıştı̆̆ım okulu eleştirdiğinde, bunu şahsıma yönelik yapılmış } \\
\text { olumsuz bir eleştiri, hakaret olarak algılarım.” }\end{array}$} & - & - & 0,763 \\
\hline \multicolumn{2}{|c|}{$\begin{array}{l}\text { ÖÖ2. "Başka insanların çalıştığım okul hakkında ne düşündüklerini çok fazla } \\
\text { önemserim." }\end{array}$} & - & - & 0,762 \\
\hline \multicolumn{2}{|c|}{$\begin{array}{l}\text { ÖÖ3. "Çalıştı̆̆ım okuldan bahsederken; "onlar" yerine "biz"” ifadesini } \\
\text { kullanırım." }\end{array}$} & - & - & 0,760 \\
\hline \multicolumn{2}{|c|}{$\begin{array}{l}\text { ÖÖ6. "Eğer, medyada çalıştığım okul hakkında olumsuz yönde eleştirel bir } \\
\text { haber çıkmıssa (çıkarsa) bundan rahatsızlık hisseder; utanç duyarım." }\end{array}$} & - & - & 0,745 \\
\hline Cronbach Alpha $(\alpha)$ & \multicolumn{4}{|l|}{0,874} \\
\hline Açıklanan Toplam Varyans & \multicolumn{4}{|l|}{$\% 61,497$} \\
\hline KMO & \multicolumn{4}{|l|}{0,866} \\
\hline Bartlett's Testi/df & \multicolumn{4}{|l|}{$2019,916 / 15$} \\
\hline DFA Uyum İndeksleri & \multicolumn{4}{|c|}{$\begin{array}{c}\chi^{2}=17,554, \mathrm{sd}=7, \chi^{2} / \mathrm{sd}=2,508, \mathrm{p}=0,000, \mathrm{CFI}=0,995, \mathrm{GFI}=0,992, \\
\mathrm{NFI}=0,991, \mathrm{RMR}=0,018, \mathrm{RMSEA}=0,046, \mathrm{AGFI}=0,976\end{array}$} \\
\hline
\end{tabular}

YEM'de yapılan DFA sırasında kullanılan ölçeklerin faktör yapıları incelenerek belli kriterler sınırında kabul edilebilir uyum değerleri oluşturup oluşturmadıklarına bakılmıştır. İfade edilen kriterlere bakıldığında; $\chi^{2} / \mathrm{sd}$ oranının iki birimin altında olması $(x \leq 2,0)$ elde edilen uyumun çok iyi olduğunu ifade ederken; üç ile beş birim arasında $(3,00 \leq x \leq 5,00)$ olmasıysa elde edilen uyumun kabul edilebilir uyumu ortaya koymaktadır. RMSEA değerinin 0,08 ile 0,05 arasında olması iyi uyum değerini, 0,05'in altında bir değerde olması ise çok iyi bir uyum elde edildiğini ifade etmektedir. CFI ve NFI değerlerinin 0,90-1,00 arasında ve GFI değerinin 0,85 ile 0,90 arasında yer alması ise iyi bir uyumun elde edildiğini belirtmektedir (Byrne, 2010; Kline, 2011).

\section{4. Önerilen Model İçin Doğrulayıcı Faktör Analizi}

YEM'de yapılan DFA, araştırmaya konu olan değişkenlere ait tüm ölçekler için uygulanmıştır. Ölçeklerden hiçbir madde silinmemiştir. Hata kovaryansları ise; Şekil 2' de de gösterildiği üzere PA1 ile PA2 ve PA6, PA2 ile PA3, EL1 ile EL2, EL2 ile EL9, EL9 ile EL10, ÖÖ1 ile ÖÖ2, ÖÖ3 ile ÖÖ5 ve ÖÖ4 ile ÖÖ5 arasına eklenmiştir. Çünkü, eklenen maddelerin hata değerlerinin birbiri arasında ilişkili olduğu görülmüştür. Yapılan ölçüm modeli, kullanılan ölçeklerin veriyle iyi düzeyde kabul edilebilir uyum içinde olduğunu göstermektedir $\left(\chi^{2}=\right.$ 495,415 $\mathrm{sd}=218, \chi^{2} / \mathrm{sd}=2,273, \mathrm{p}=0,000, \mathrm{CFI}=0,974, \mathrm{GFI}=0,945$, NFI=0,955，RMR=0,049，RMSEA=0,042， AGFI=0,931). Ayrıca, oluşturulan ölçüm modelindeki gizil değişkenlerin birbirleriyle anlamlı ilişki içinde olduğu bulgulanmıştır. 


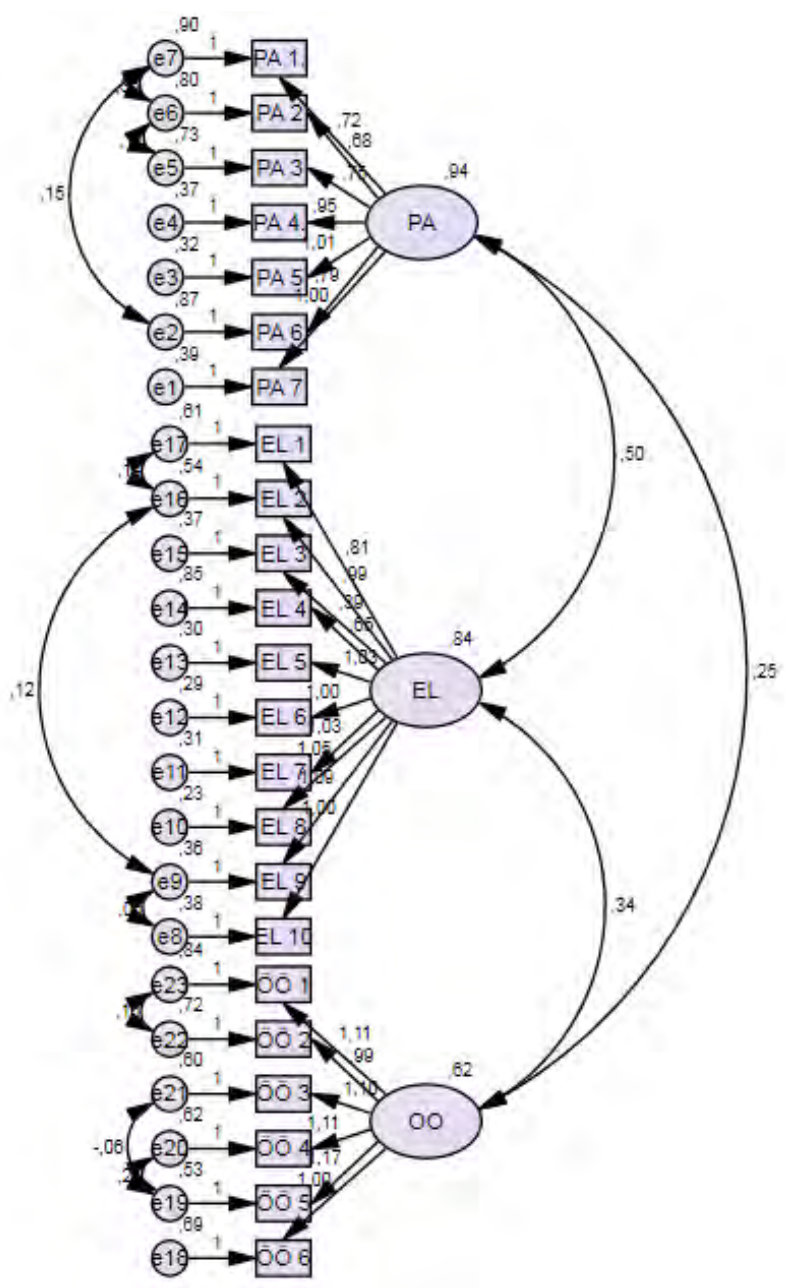

Şekil 2. Standardize edilmiş katsayılarla ölçüm modeli

\section{5. Önerilen Modele İlişskin Yapısal Eşitlik Modeli}

Araştırmaya dahil olan öğretmenlerin prosedürel adalet algısı ve örgütsel özdeşleşmeleri arasındaki ilişki ve bu ilişkide etik liderliğin aracılık rolünü test edebilmek amacıyla kurulan kavramsal araştırma modeli, YEM'de Baron ve Kenny (1986: 1176) tarafından ortaya konulan yaklaşımla test edilmiştir. Araştırmacılar tarafından öne sürülen bu yaklaşımda takip edilmesi gereken adımlar için tek tek yol (path) analizleri gerçekleştirilmiştir. İlk olarak, bağımsız değişken olan prosedürel adalet algısının bağımlı değişken konumundaki örgütsel özdeşleşme üzerindeki etkisi test edilmiştir. Oluşturulan regresyon yolunun (PA $\rightarrow$ OO: Stand. $\beta=0,415$, Stand. hata $=0,059, p=0,000$ ) kat sayılarının anlamlı olduğu anlaşılmaktadır. Ayrıca, kurulan regresyon yolu için DFA sonuçları da $\left(\chi^{2}=116,972\right.$, sd $=58, \chi^{2} / \mathrm{sd}=2,017, \mathrm{p}=0,000, \mathrm{GFI}=0,976, \mathrm{CFI}=0,988$, $\mathrm{NFI}=0,976, \mathrm{RMR}=0,044, \mathrm{RMSEA}=0,038$, AGFI=0,963) bu anlamlılığı destekler niteliktedir. Aracılık rolünün test edilmesinde ilk adımın yerine getirilmesinin ardından ikinci adımda ise, bağımsız değişken olan prosedürel adalet algısının aracı değişken olan etik liderlik üzerindeki etkisinin varlığı sorgulanmıştır. İkinci adım için yapılmış olan analiz sonrasında değişkenler arasında anlamlı bir ilişkinin (PA $\rightarrow$ EL: Stand. $\beta=0,744$, Stand. hata $=0,062, \mathrm{p}=0,000$ ) olduğu elde edilen yol katsayıları yardımıyla tespit edilmiştir. DFA sonuçlarıyla da $\left(\chi^{2}=263,843\right.$ sd=110, $\chi^{2} / \mathrm{sd}=2,399, \mathrm{p}=0,000, \mathrm{GFI}=0,959 \mathrm{CFI}=0,982, \mathrm{NFI}=0,969$, RMR=0,040, RMSEA=0,044, AGFI=0,944) bu ilişki doğrulanmıştır. Takip eden adımda ise aracı değişken olan etik liderliğin bağımlı değişken olan örgütsel özdeşleşme üzerindeki etkisini tespit etmek suretiyle yeni bir regresyon modeli oluşturulmuştur. Yapılan analize göre (EL $\rightarrow$ OO: Stand. $\beta=0,478$, Stand. hata=0,044, $p=0,000$ ) anlamlı olduğu sonucu tespit edilmiştir. Bunun yanı sıra DFA sonuçları da $\left(\chi^{2}=233,601\right.$, sd=95, $\chi^{2} / \mathrm{sd}=2,459, \mathrm{p}=0,000, \mathrm{GFI}=0,962$, $\mathrm{CFI}=0,982, \mathrm{NFI}=0,970, \mathrm{RMR}=0,046$, RMSEA=0,045, AGFI=0,946) bunu destek durumdadir.

Baron ve Kenny yaklaşımına göre aracılık rolünün test edilebilmesi için gerekli olan ilk şartların yerine getirilmesiyle dördüncü adım olan prosedürel adalet algısı örgütsel özdeşleşme arasındaki ilişkide, etik liderliğin aracılık rolünün olup olmadığını görebilmek amacıyla bir yol analizi modeli kurulmuştur. Kurulan 
ölçüm modelinin verilerle olan uyumunun iyi düzeyde elde edilmesinden sonra gizil değişkenler arasındaki kovaryanslar silinerek kuramsal çerçeveye uygun olacak şekilde tek yönlü yollar eklenmiştir (Bknz.: Şekil 3). YEM'in de eldeki verilerle kabul edilebilir uyum içinde olduğu tespit edilmiştir $\left(\chi^{2}=501,315\right.$ sd=218, $\chi^{2} / \mathrm{sd}=2,300, \mathrm{p}=0,000, \mathrm{CFI}=0,974, \mathrm{GFI}=0,945, \mathrm{NFI}=0,954, \mathrm{RMR}=0,049, \mathrm{RMSEA}=0,042, \mathrm{AGFI}=0,930$ ).

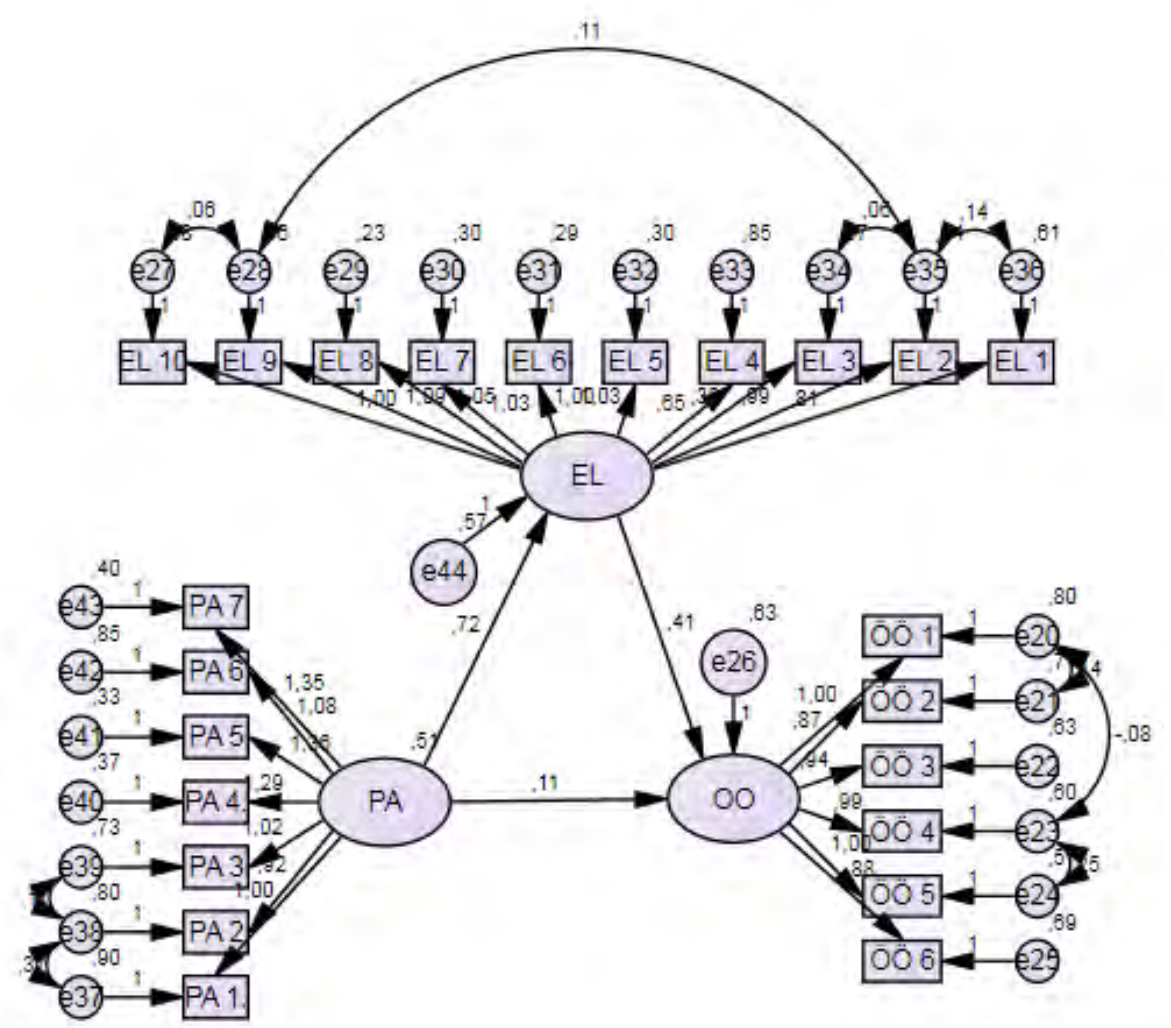

Şekil 3. Standardize edilmiş yol katsayıları ile son yapısal eşitlik modeli

Aracılık testi için izlenen ilk üç adımda elde edilen bulgular ve Şekil 3'te görüldüğü gibi bağımsız değişken olan prosedürel adalet algısının bağımlı değişken olan örgütsel özdeşleşme üzerindeki anlamlı etkisinin ilk durumdaki etkisine (PA $\rightarrow \mathrm{OO}$ : Stand. $\beta=0,415$, Stand. hata $=0,059, \mathrm{p}=0,000)$ göre azalmış olduğu ve hatta anlamlılığını (Stand. $\beta=0,112$, Stand. hata $=0,061, p=0,066$ ) kaybettiği görülmüştür. Ayrıca; etik liderliğin örgütsel özdeşleşme üzerindeki anlamlı etkisinin ( $\mathrm{EL} \rightarrow \mathrm{OO}$ : Stand. $\beta=0,478$, Stand. hata $=0,044, p=0,000$ ) bağımsız değişken olan prosedürel adalet algısı değişkeni ile modele dâhil edilmesinden sonra da (Stand. $\beta=0,413$, Stand. hata=0,050, $\mathrm{p}=.000$ ) devam ettiği tespit edilmiştir. Ulaşılan bu sonuçlara bağlı kalınarak, bağımsız değişken durumundaki prosedürel adalet algısı ile birlikte modele dâhil edilmiş olan aracı değişken durumundaki etik liderliğin, tam aracılık etkisi oluşturduğu rahatlıkla ifade edilebilmektedir. Bunun yanı sıra, aracılık rolünün test edilebilmesi için oluşturulan regresyon modelinin uyum indeksleri de ilgili modelin kabul edilebilir iyi uyum aralığında olduğunu belirtmekte ve etik liderliğin aracılık rolü oluşturduğunu doğrulamaktadır.

Bunun yanı sıra, "kısmi veya tam aracılğ̆ın oluşmasında, bağımsız değişken tarafından açıklanan varyanstaki azalmanın anlamlılı̆̆ıı ölçen bir yöntem" (Sobel, 1982) olan Sobel testi yardımıyla bir test daha yapılarak prosedürel adalet algısıyla örgütsel özdeşleşme arasındaki ilişkide ara değişken rolünü tespit edebilmek amaçlanmıştır. Yapılan testin sonucuna göre, etik liderlik alt faktörü için $t$ istatistiğinin değeri 2,47 olarak bulunmuştur ve p değerinin de 0,01 'den daha küçük olduğu görülmüştür. Böylece, etik liderliğin modele dâhil edilmesi neticesinde, prosedürel adalet algısıyla örgütsel özdeşleşme arasındaki ilişkinin anlamlı olarak azaldığı (hatta ortadan kalktığı), etik liderliğin tam aracı değişken rolünün anlamlı olduğu görülmüştür. 


\section{SONUÇ ve TARTIŞMA}

Araştırmada İstanbul'un Kadıköy, Maltepe, Ataşehir, Üsküdar ilçelerinde eğitim vermekte devlet okulundaki öğretmenlerin prosedürel adalet algıları ile örgütsel özdeşleşmeleri arasındaki ilişkide etik liderlik uygulamalarının aracılık rolünü belirlemek amaçlanmıştır. Belirlenen bu temel motivasyondan yola çıkılarak öncelikle araştırmaya konu olan değişkenlerin kısa açıklamaları ve aralarındaki ilişkiler ifade edilmiştir. Yapılan ulusal ve uluslararası alan araştırması ve kavramsal çerçeve dahilinde belirlenmiş olan hipotezler test edilerek, değişkenler arasındaki ilişki ve düzeylerine ilişkin olarak aşağıdaki bulgular elde edilmiştir. Öncelikle bağımlı değişken olan örgütsel özdeşleşme ile bağımsız değişken olan prosedürel adalet algısı ve aracı değişken olan etik liderlik değişkenleri arasındaki ilişkilerin varlığı sorgulanmıştır. Yapılan korelasyon analizi neticesinde prosedürel adalet algisıyla örgütsel özdeşleşmenin pozitif korelasyon içinde birçok araştırmada (Brewer ve Kramer, 1986: 545; Farh vd., 1997: 433; Masterson vd., 2000; Başar, 2011: 151; Öktem, 2013:17; Taşlıyan vd., 2017: 10) olduğu gibi benzer durumda görülmüştür. Örgütteki çalışanları ve örgütün elde ettiği çıktıları etkileyen kararların verilme süreci ve bu mekanizmaların işleyişindeki adalet algısını ifade eden prosedürel adalet algısı, yapılan ve yapılacak olan işlerle alakalı yaşanacak resmi değişiklikler, örgütün politika ve prosedürlerinde olabilecek değişiklikler, yöneticiler tarafından alınan kararlarda takip edilen yöntemler, kararların alınması ve adil olup olmamasının durumu çalışanların örgütleriyle özdeşleşmeleri üzerinde pozitif yönde anlamlı bir etkisinin olduğu bulunmuştur. Bu durumda, $\mathrm{H}_{1}$ : Okullarda prosedürel adalet algılamasını, öğretmenlerin örgütsel özdeşleşmelerine olumlu etkisi bulunmaktadır hipotezi desteklenmiştir.

Örgüt içindeki işleyişte adaletin doğrudan gözlemlenebilmesi için çaba sarf eden etik liderler (Brown vd., 2005), süreçlerin yönetilmesinde de buna çok dikkat etmektedir. Örgüt içinde yaşanan terfi, ödül, ceza, ücretlendirme vb. durumların hakkaniyetli ve adaletli bir şekilde yapılıyor olması çalışanların gözünde adalet algısını artıracağı gibi; liderin etik değerlere bağlılı̆ın olduğunu da ortaya koyacaktır. Süreçlerin sağlıklı ilerletilmesi, alınan kararlara çalışanlarca itiraz etme hakkının sunulması, çalışanların görüş bildirebilmeleri doğrudan etik liderin kendini daha rahat öne çıkarmasına hizmet edebilmektedir. Çünkü etik liderler çalışanlarının görüşlerine önem vermektedirler. Örgütte algılanan adalet ne denli yüksek olursa yöneticinin etik liderlik vasfı da o denli gözlemlenebilecektir. Yapılan korelasyon analizi neticesinde, prosedürel adalet algısıyla etik liderliğin pozitif korelasyon içerinde olduğu benzer çalışmalarda da (Uğurlu ve Üstüner, 2011; Acar vd., 2012; Kugun vd., 2013: 160; Çıraklı vd., 2014; Ayık vd., 2014; Akatay vd., 2016; Büyükyılmaz ve Ay, 2017) görülmektedir. Bu durumda, $H_{3}$ : Okullarda prosedürel adalet algısının, etik liderlik uygulamalarına olumlu etkisi bulunmaktadır hipotezi doğrulanmaktadır.

Öte yandan aracı değişken rolündeki etik liderliğin de örgütsel özdeşleşmeyle pozitif korelasyon içinde olduğu çeşitli araştırmalarda olduğu gibi (Grojean vd., 2004: 229; Yeşiltaş, 2012; Öktem, 2013:17; Palalar Alkan ve Arıkboğa, 2017; 354; Kılınç, 2017) bulgulanmıştır. Değişkenler arasındaki ilişkilerin tespit edilmesinden sonra aracılık rolünün varlığını sorgulamak amacıyla YEM'de yol analizi yapılmıştır. Yapılan yol analizi sonuçlarına bakıldığında; bağımsız değişken olan prosedürel adalet algısının örgütsel özdeşleşme üzerindeki etkisi, aracı değişken olan etik liderliğin de analize alınması sonucunda ortadan kalkmıştır. Ayrıca tüm değişkenler birlikte analize alındığında, örgütsel özdeşleşmeye yönelik olarak, çalışanların örgüt içinde prosedürel adalet algısından daha çok yöneticilerinin etik liderlik davranışlarına daha fazla öncelik verdiği anlaşılmaktadır. Çalışanların, ödüller, görev, sorumluluklar, vb. unsurların işletilmesi süreçlerinde adaletli olunmasında yöneticinin etik liderlik vasıflarını hayata geçiriyor olmasının çok ilişkili olduğu görülmektedir. Bulguların istatistiki değerlerine bakıldığında (Bkz: Şekil 3) etik liderliğin bahsi geçen bu ilişkide tam aracılık rolü üstlendiği rahatlıkla söylenebilmektedir. Bu durumda, $\mathbf{H}_{2}$ : Okullarda etik liderlik uygulamalarmm, öğretmenlerin örgütsel özdeşleşmelerine olumlu etkisi bulunmaktadır ve $\boldsymbol{H}_{4}$ : Okullarda prosedürel adalet algilamasının öğretmenlerin örgütsel özdeşleşmelerine etkisinde etik liderlik uygulamalarının aracılık rolü bulunmaktadır hipotezi doğrulanmaktadır. Elde edilen bulgular yazındaki birçok çalışmayla paralellik göstermekte olup kurulan tüm hipotezlerin doğrulandığını göstermektedir. Bu araştırmadaki sonuçların yazındaki çoğu araştırmanın sonuçlarıyla benzer içinde olmasından öte örgütsel adalet algısının yalnızca tek bir alt boyutunu ele alması önem arz etmektedir. Çünkü, prosedürel adalet algısı, etik liderlik davranışlarının çok daha açık ve net olarak anlaşılmasında önemli bir unsurdur. Nitekim liderin söylem ve eylemlerinin değerlendirilmesi için bir fırsat niteliğindedir. Prosedürel adalet algıSı, çalışanların yöneticilerinin sahip olduğunu ifade ettiği etik değerleri uygulamada birebir sunması için bir etki mekanizması olarak da değerlendirilebilir.

$\mathrm{Bu}$ araştırmanın bulgularına ve sonuçlarına bağlı olarak yöneticilere bazı öneriler olacaktır. Makineleşmenin 


\section{S. Aksoy Kürü 12/4 (2020) 3895-3913}

neredeyse hiç olmadığı ve insan ilişkilerinin maneviyata dayalı bir iş olduğu öğretmenlik mesleğinden kök alınarak, eğitim öğretim sektöründe liderin ahlaki standartları hayata geçiriyor olması çok önemlidir. Nitekim hem iş yapış sürecinde hem karar alınması ve uygulanması sürecinde hem de okul içinde bir bütünlük yakalayabilmede etik liderlik davranışlarının etkisi yadsınamaz düzeydedir. Bir kılavuz görevi gören etik liderler, çalışanlar için kıymetli birer rehber niteliğindedirler. İş ve özel yaşantısında benimsediği etik yaşama tavrı kaçınılmaz olarak çalışma ortamında kendini göstermektedir. Bu sayede de rol model olarak yapıcı sonuçlara ulaşmaya imkân doğmaktadır. Liderini benimseyen ve onun ahlak anlayışının yapıcı sonuçlarını gören çalışanlar hem lideriyle hem de örgütüyle bir uyum yakalayacaktır ve bunun sonucunda da örgütüyle özdeşleşme gerçekleşecektir. Örgüt içindeki prosedürlerin açık ve net olarak çalışanlara bildirilmesi ve daha da önemlisi bunların etik ve ahlaki standartlara uygun bir biçimde uygulanabiliyor olması liderin etik manada işlerin nasıl doğru yapılacağı konusunda bir örnek teşkil ettiği bilincini çalışanların bilincine yerleştirecektir. Ayrıca, yöneticinin etik liderlik davranışlarından biri olan adil ve dengeli karar alabilmesi, çalışanda yöneticiye karşı güven ve çalışma ortamı için bir motivasyon kaynağı oluşturmaktadır. Bu sayede de örgütün içinde çalışan sesliliği sağlanarak tıpkı ailenin bir üyesi hissiyata çalışanlara geçecektir. Çalışanlarının fikirleriyle yakından ilgilenen etik liderler, aidiyet ve bütünleşme için kilit noktadır denebilir. Bu da çalışanlara "ben" olmaktan öte "biz" olmayı benimsetecek ve örgüt dışında da böyle anılmayı tetikleyecektir. Bilişsel ve duygusal bir kabullenme olan örgütsel özdeşleşme için hem prosedürel adalet algısının hem de etik liderlik davranışlarının açıkça gözlenebiliyor olması örgütün başarılarının çalışanın başarısı gibi kabullenmesi için bir nedendir. Benzer şekilde de bu süreçlerin işleyiş̧inde yaşanan olumlu ve/veya olumsuz tecrübeler sonucunda örgütün övgü veya tepki alması yine çalışan tarafından içselleştirilerek bireyselleştirilecek kadar ileri seviyeye varabilmektedir. Çünkü, örgütüyle özdeşleşen bir çalışan için "onlar" değil "biz" ifadesi oluşmuştur. Toparlandığında, yöneticinin çatışmadan uzak bir tavır güderek ve hatta gerekli durumlarda yapıcı çatışma yaşanması halinde mutlaka etik ve ahlaki standartları kendine rehber edinmesi gerekmektedir denebilir. Okul yöneticilerinin alınacak bir karar durumunda bu kararın sonuçlarından etkilenecek olan öğretmenin ya da zümrenin görüşünü ve onayını alması gerekmektedir. Bu durumda daima açık iletişim içinde olmaları önerilebilir. İletişimin açık ve anlaşılır olmasıyla söz hakkına sahip olan öğretmen, okulunu yalnızca bir iş yeri olarak görmeyecek adeta değerlerin paylaşıldığı bir yuvası olarak nitelendirecektir. Okul yöneticilerinin karşılaştıkları hatalı ya da kusurlu bir uygulama karşısında uygun değerlendirmeler yapması ve bunu da okuldaki öğretmenlerle yine uygun ve anlaşılır bir şekilde paylaşması önerilecek bir başka unsurdur. Yani kabul edilemeyecek durumdaki bir uygulamayı hangi öğretmen yaparsa yapsın eşitlik ve adaletli davranıştan uzaklaşmadan gerekirse cezai uygulamaya yönelmesi ve bunu da diğer öğretmenlere bir ikaz niteliğinde de bildirmelidir. Kendisinin de bir rol model olduğunu daima bilmesi ve buna göre hareket etmesi de bir diğer öneri niteliğindedir.

Gelecekteki araştırmacılara yönelik önerilerde ise, günümüz çalışma yaşamında en önemli değerin insan olduğu değişmez bir gerçek olduğu vurgusunun yapılması daima ilk sırada yer almalıdır. Bunun yanı sıra, yetişmiş ve eğitimli iş gücü çok daha kıymetlidir. Öğretmenler de bu kıymetli iş gücünün birer örneğidir. Özverili çalışma yapıları ve duygusal yönleri yüksek olan sorumluluk sahibi olma gibi de kıymetli özellikleri olan öğretmenlik mesleğinin okullardaki yönetim anlayışından ve süreçlerden etkilenmesi diğer mesleklerde de olduğu gibi kaçınılmazdır. Bu nedenle de etraflıca düşünerek kapsamlı bir şekilde ele alınması gereken, araştırmamızdaki değişkenlerin dışında da çok fazla kavram vardır. Örneğin mesleki bağlılık, örgütsel güven, işe adanmışlık, kişilik gibi daha birçok kavram ele alınıp irdelenerek öğretmenlerin örgütleriyle özdeşleşmelerinde öncül ve ardıl olabilecek unsurlar üzerinde araştırmalar yapılabilir. Bu araştırmada yalnızca nicel bir yöntem kullanılmış olduğu için ilerleyen dönemlerde bu çalışmayı nitel yöntemlerle de zenginleştirebilmek olasıdır. Yalnızca devlet okullarında çalışan öğretmenler üzerinde yürütülen çalışmamızı yeni araştırmacılar özel okullarda çalışan öğretmenler üzerinde de yaparak mukayeseli bir çalışma gayreti güdebilirler. Ulaşım, erişim, zaman ve emek maliyetlerini gözeterek araştırmacıların lokasyon olarak yakı buldukları coğrafi bölgeyle sınırlı kalan bu araştırma, doğu, batı, kuzey ve güney bölgeler olmak üzere coğrafi ve sosyo-kültürel farklılıklara da yer verilmek amacıyla bölgesel ve hatta imkân olursa ulusal ölçekte çok daha kapsamlı bir çalışma yürütebilirler. 


\section{KAYNAKÇA}

Acar, G., Kaya, M. ve Şahin, M. Y. (2012). School administrators ethical leadership behavior effects on physical education teachers organizational justice level, Turkish Journal of Sport and Exercise, 14(3), 51-58.

Adams, J. S. (1965). Inequity in Social Exchange, içinde Berkowitz, L (Ed.), Advances in Experimental Social Psychology, Academic Press, New York London, 2, 267-299.

Akatay, A., Kısat, N. Ç. ve Yücekaya, P. (2016). Yöneticilerin etik liderlik davranışlarının, örgütsel adalet ve sinizm üzerine etkileri: Çanakkale İl Emniyet Müdürlüğü'nde bir araştırma, Yönetim Bilimleri Dergisi, 14(28), 483-509.

Akıllı, H. S., Çam, S., Kılınç S. ve Kızılboğa, R. (2013). Kamu personelinin etik ihlallerine verdikleri önem derecesi ve etik ihlallerin bildirimi konusundaki görüşleri, Sayıştay Dergisi, 89, 20-30.

Alberth, S., Ashforth, B. E., ve Dutton, J. E. (2000). Organizational identity and identification: Charting new waters and building new bridges, Academy of Management Review, 25(1), 13-17.

Alexander, S. ve Ruderman, M. (1987). The role of procedural and distributive justice in organizational behavior, Social Justice Research, 1: 177-98.

Alexander, S., Sinclair, R. R. ve Tetrick, L. E. (1995). The Role of Organizational Justice in Defining and Maintaining the Employment Relationship içinde Tetrick, L.E. and Barling, J. (Ed.) Changing Employment Relations: Behavioral and Social Perspectives. Washington, DC: American Psychological Association.

Arı, G. S., Bal, H., ve Bal, E. Ç. (2010). İşe bağlılığın tükenmişlik ve işten ayrılma niyeti ilişkisindeki aracılık etkisi: yatırım uzmanları üzerinde bir araştırma, Süleyman Demirel Üniversitesi İktisadi ve İdari Bilimler Fakültesi Dergisi. 15 (3), 143-166.

Ashforth, B. E., Harrison, S. H., ve Corely, K. G. (2008). Identification in organizations: An examination of four fundametal questions, Journal of Management, 34, 325-374.

Ayık, A., Yücel, E. ve Savaş, M. (2014). Öğretmenlerin örgütsel adalet algılarının yordayıcısı olarak okul yöneticilerinin etik liderlik davranışları, Abant İzzet Baysal Üniversitesi Eğitim Fakültesi Dergisi, 14(2), 233-252.

Balcı, A. (2004). Sosyal Bilimlerde Araştırma: Yöntem, Teknik ve İlkeler. (4.Baskı). Ankara: Pegema Yayıncılık.

Baron, M. ve Kenny, D. A. (1986). The moderator-mediator variable distinction in social psychological research: Conceptual, strategical statistical considerations. Journal of Personality and Social Psychology, 51(6), 1173-1182.

Bartlett, J. E., Körtlik, J. W. ve Higgins, C. C. (2001). Organizational research: Determining appropriate sample size in survey research, Information Technology, Learning and Performance Journal, 19(1), 43-50.

Başar, U. (2011). Örgütsel Adalet Algısı, Örgütsel Özdeşleşme ve İş Tatmini Arasındaki İlişkilere Yönelik Görgül Bir Araştırma. Yayımlanmamış Yüksek Lisans Tezi. Kara Harp Okulu Savunma Bilimleri Enstitüsü Savunma Yönetimi Ana Bilim Dalı, Ankara.

Bayram, N. (2016). Yapısal Eşitlik Modellemesine Giriş: AMOS Uygulamaları. Bursa: Ezgi Kitabevi.

Beugre, C. D. (1998). Managing Fairness in Organization. West port, CT: Quorum Books.

Brewer, M. B. ve Kramer, R. M. (1986). Choice behavior in social dilemmas: effects of social identity, group size and decision framing, Journal of Personality and Social Psychology, 50, 543-549.

Brown M. E., Treviño, L. K. ve Harrison, D. A. (2005). Ethical leadership: a social learning perspective for construct development and testing, Organizational Behavior and Human Decision Processes 97(2), 117134.

Büyüköztürk, Ş., Çakmak, E.K., Akgün, Ö.E., Karadeniz, Ş. V. ve Demirel, F. (2012). Bilimsel Araştırma Yöntemleri. Pegem A Yayıncılık, Ankara.

Büyükyılmaz, O. ve Ay, F. A. (2017). Etik liderliğin örgütsel vatandaşlık davranışına etkisinde örgütsel adaletin aracılık rolü, Hitit Üniversitesi Sosyal Bilimler Enstitüsü Dergisi, 10(1), 209-233. 


\section{S. Aksoy Kürü 12/4 (2020) 3895-3913}

Byrne, B. M. (2010). Structural Equation Modeling With AMOS: Basic Concepts, Applications, and Programming, Second Edition (Multivariate Applications Series), Routledge Publishing.

Castillo, C. ve Fernández Alarcón, V. (2017). Relationships between the dimensions of organizational justice and students' satisfaction in university contexts, Intangible Capital, 13(2), 282-301.

Chang, E., (2002) "Distributive Justice and Organizational Commitment Revisited: Moderation by Layoff in the Case of Korean Employees", Human Resource Management, 41(2).

Cheney, G. (1983). On the various and changing meanings of organizational membership: A field study of organizational identification, Communication Monographs, 50(4), 342-362.

Colquitt, J. A. (2001). On the dimensionality of organizational justice: a construct validation of a measure, Journal of Applied Psychology, 86(3), 386.

Cropanzano, R. ve Ambrose, M. L. (2001). Procedural and Distributive Justice Are More Similar Than You Think: A Monistic Perspective and a Research Agenda. In J. Greenberg \& R. Cropanzano (Eds.), Advances in organizational justice (119-151). Stanford, CA: Stanford University Press.

Cropanzano, R. S. ve Kackmar, K. M. (1995). Organizational Politics, Justice and Sup- port: Managing the Social Climate of the Workplace, West port, Ct: Quorum Books.

Cropanzano, R. S. ve Randall, M. L. (1993). Injustice and Work Behaviour: a Historical Review içinde Cropanzano, R.S. (Ed.) Justice in the Workplace: Approaching Fairness in Human Resource Management. Hillsdale, Nj: Lawrence Erlbaum, 3-20.

Çelik, H. E. ve Yılmaz, V. (2016). Yapısal Eşitlik Modellemesi, Temel Kavramlar, Uygulamalar, Programlama, Anı Yayıncilık, Ankara.

Çıraklı, U., Uğurluoğlu, O., Şantaş, F. ve Çelik, Y. (2014). Etik liderlik davranışlarının örgütsel adalet üzerindeki etkisi: hastanede bir uygulama, İşletme Bilimi Dergisi, 2(2), 53-69.

DeConinck, J. B. ve Stilwell, C. (2004). Incorporating organizational justice, role states, pay satisfaction and supervisor satisfaction in a model of turnover intentions, Journal of Business Research, 57, 225-231.

Edwards, M. R. (2005). Organizational identification: A conceptual and operational review, International Journal Of Management Review, 7 (4), 207- 230.

Elçi, M., Şener, İ., ve Aksoy, S. (2012). Etik liderliğin etik iklime, birey-örgüt performansına etkileri. 20. Ulusal Yönetim Organizasyon Kongresi, İzmir.

Farh, J. L., Earley, P. C. ve Lin, S. C. (1997). Impetus for action: a cultural analysis of justice and organizational citizenship behavior in Chinese society, Administrative Science Quarterly, 42: 421-444.

Folger, R. (1987). Reformulating The Preconditions of Resentment: A Referent Cognitions Model. In (Eds.) J. C. Masters \& W. P. Smith, Social Comparison, Justice, and Relative Deprivation: Theoretical, Empirical, And Policy Perspectives (183-215). Hillsdale, NJ: Lawrence Erlbaum Associates.

Folger, R. (1989). Significance tests and the duplicity of binary decisions, Psychological Bulletin, 106(1), 155-160.

Folger, R. ve Cropanzano, R. S. (1998). Organizational Justice and Human Resource Management, Thousand Oaks, CA: Sage.

Folger, R. ve Konovsky, M. A. (1989). Effects of procedural and distributive justice on reactions to pay raise decisions, Academic Management Journal, 32(1), 115-30.

Fryxell, G. E. ve Gordon, M. E. (1989). Workplace justice and job satisfaction as predictors with unions and management, Academy of Management Journal, 32, 851-66.

Gilliland, S. W. ve Chan, D. (2009). Örgütsel Adalet: Teori, Yöntemler ve Uygulamalar içinde N. Anderson, D. S. Ones, H. K. Sinangir, C. Viswesvaran (ed.). Endüstri, İş ve Örgüt Psikolojisi El Kitabı, Cilt 2, İstanbul: Literatür Yayıncılık, 167-194.

Gordon, M. E. ve Fryxell, G. E. (1993). The Role of Interpersonal Justice in Organizational Grievance Systems içinde Cropanzano, R. (Ed.) Justice in Tiie Workplace: Approaching Fairness in Human Resources Management. 
Hillsdale, Nj: Lawrence Eribaum, 231-55.

Gossett, L. (2002). Kept at arm's length: Questioning the organizational desirability of member identification, Communication Monographs, 69(4), 385-404.

Greenberg, J. (1987). A taxonomy of organizational justice theories, Academy of Management Review, 12, 9-22.

Greenberg, J. (1988). Cultivating an image of fairness: looking fair on the job, Journal of Applied Psychology. 73, 606-13.

Greenberg, J. (1990). Organizational justice: yesterday, today and tomorrow, Journal of Management, 16, 399432.

Greenberg, J. (1993). Justice and Organizational Citizenship: A Commentary on the State of Science, Employee Responsibility and Rights Journal, 6, 249-56.

Greenberg, J. (1996). The Quest For Justice: Es. Says and Experiments, Thousand Oaks, CA: Sage.

Grojean, M. W., Resick, C. J., Dickson, M. W. ve Smith, D. B. (2004). Leaders, values and organizational climate: Examining leadership strategies for establishing an organizational climate regarding Ethics, Journal Of Business Ethics, 55, 223-241.

Hall, D. T., Schneider, B. ve Nygren, H. T. (1970). Personel factor in organizational identification, Administrative Science Quarterly, 176-191.

Hartley, J. (1995). Challenge and Change in Employment Relations: Issues For Psychology, Trade Unions and Managers içinde Tetrick, L.E. ve Barling, J. (Ed.) Changing Employment Relations: Behavioural and Social Perspectives. Washington, DC: American Psychological Association.

Harvey, E. (2004). Liderlik ve etik, Executive Excellence, 8(87), 23.

Hodgetts, R. M. ve Luthans, F. (2003). International Management, Culture, Strategy and Behavior, NY: McGraw Hill/Irwin.

İçerli, L. (2010). Örgütsel Adalet: Kuramsal Bir Yaklaşım. Girişimcilik ve Kalkınma Dergisi, (5) 1, $63-88$.

İşcan, Ö. F. (2006). Dönüştürücü etkileşimci liderlik algısı ve örgütsel özdeşleşme ilişkisinde bireysel farklılıkların rolü, Akdeniz Üniversitesi İktisadi ve İdari Bilimler Fakültesi Dergisi, 11, 160-177.

İyigün, N. Ö. (2012). Örgütsel adalet: Kuramsal bir yaklaşım, İstanbul Ticaret Üniversitesi Sosyal Bilimler Dergisi, $11(21), 49-64$.

Karasar, N. (2012). Bilimsel Araştırma Yöntemi. Ankara: Nobel yayıncılık.

Katrinli, A., Atabay, G., Günay, G. ve Güneri B. (2008). Leader-member exchange, organizational identification and the mediating role of job involvement for nurses, Journal of Advanced Nursing, 64 (4), 354-362.

Kılınç, S. (2017). Yöneticilerin Etik Liderlik Davranışlarının Örgütsel Özdeşleşme, Sapkın Davranışlar ve Sinizme Etkisi. Yayımlanmamış Yüksek Lisans Tezi, Nevşehir Hacı Bektaş Veli Üniversitesi Sosyal Bilimler Enstitüsü İşletme Anabilim Dalı, Nevşehir.

Kline, R. B. (2011). Principles and Practice of Structural Equation Modeling. New York: The Guilford Press.

Kugun, O. A., Aktaş, E. ve Güripek, E. (2013). Çalışanların örgütsel adalet algılarında yöneticilerinin etik liderlik davranışlarının rolü, Balıkesir University The Journal of Social Sciences Institute, 16(30), 151-166.

Lee, S. M. (1971). An empirical analysis of organizational identification, The Academy of Management Journal, $14(2), 213-226$.

Leventhal, G. S. (1980). What Should Be Done with Equity Theory? New Approaches to the Study of Fairness in Social Relationships içinde Gergen, K. Greenberg, M., ve Willis, R. (Ed.), Social Exchange: Advances in Theory and Research, New York: Plenum Press.

Lind, E. A. (1995). Justice and Authority in Organizations içinde Cropanzano, R. ve Kacmar, K.M. (Ed.) Organizational Politics, Justice and Support. Westport, Ct: Quorum Books, 83-96. 
Lind, E. A. ve Tyler, T. R. (1988). The Social Psychology of Procedural Justice, New York and London: Plenum Pres.

Lipponen, J., Olkkonen, M. E. ve Moilanen, M. (2004). Perceived procedural justice and employee responses to an organizational merger, European Journal of Work and Organizational Psychology, 13, 391-413.

Mael, F. ve Ashforth, B. E. (1992). Alumni and their alma mater: A partial test of the reformulated model of organizational identification, Journal of Organizational Behavior, 13, 103-123.

Mael, F. ve Ashforth, B. E. (1995). Loyal from day one: Biodata, organizational identification, and turnover among newcomers, Personnel Psychology, 48 (2), 309-333.

Martocchio, J. J. ve Judge, T. A. (1995). When we don't see eye to eye: discrepancies between supervisors and subordinates in absence disciplinary decisions. Journal of Management, 21, 251-278.

Masterson, S. S., Lewis, K., Goldman, B. M. ve Taylor, M. S. (2000). Integrating justice and social exchange: the differing effects of fair procedures and treatment on work relationships, Academy of Management Journal, 43: 738- 748.

Mayer, D. M., Kuenzi, M. ve Greenbaum, R. (2010). Examining the link between ethical leadership and employee misconduct: The mediating role of ethical Climate, Journal of Business Ethics, 95, 7-16.

McFarlin, D. B. ve Sweeney, P. D. (1992). Distributive and procedural justice as predictors of satisfaction with personal and organizational outcomes, Academy of Management Journal, 35, 626-637.

Meydan, C. H. ve Şeşen, H. (2015). Yapısal Eşitlik Modellemesi, Amos Uygulamaları. Ankara: Detay Yayıncılık.

Moorman, R. (1991). Relationship between organizational justice and organizational citizenship behaviors: Do fairness perceptions influence employee citizenship? Journal of Applied Psychology, 76(6), 845-855.

Olkkonen, M. ve Lipponen, J. (2006). Relations between organizational justice, identification with organization and work unit, and group-related outcomes, Organizational Behavior and Human Decision Process, 100, 202-215.

Öktem, Ş. (2013). The effect of the ethical leadership on perceived organizational justice and organizational identification of the employees: the case of tourism businesses, Journal of Tourism and Gastronomy Studies, 1(3), 10-22.

Özmen Ö. N. T., Arbak, Y. ve Özer, P. S. (2007). Adalete verilen değerin adalet alglar üzerindeki etkisinin sorgulanmasına ilişkin bir araştırma, Ege Akademik Bakış, 7, 17-33.

Palalar-Alkan, D. ve Arıkboğa, F. Ş. (2017). Etik liderlik ve örgütsel vatandaşlık davranışı ilişkisinde örgütsel özdeşleşmenin aracılık etkisi ve bir uygulama, Manisa Celal Bayar Üniversitesi İ. İ. B. F. Yönetim ve Ekonomi Dergisi, 24(2), 349-369.

Rahman, A., Shahzad, N., Mustafa, K., Khan, M. F., ve Qurashi, F. (2016). Effects of organizational justice on organizational commitment, International Journal of Economics and Financial Issues, 6(3), 188- 196.

Riketta, M. (2005). Organizational identification: A meta-analysis, Journal of Vocational Behavior, 66, 358- 384.

Riketta, M. ve Van Dick, R. (2005). Foci of attachment in organizations: A meta- analytic comparison of the strength and correlates of work group versus organizational identification and commitment, Journal Of Vocational Behavior, 67, 490-510.

Rousseau, D. M. (1998). Why workers still identify with organizations? Journal OfOrganizational Behavior, 19(3), 217.

Sezgül, İ. (2010). Liderlik ve etik: Geleneksel, modern ve postmodern liderlik tanımları bağlamında bir değerlendirme, Toplum Bilimleri Dergisi, 4(7), 239-251.

Sheppard, B. H., Lewicki, R. J. ve Minton, J. W. (1992) Organizational Justice: the Search For Fairness in the Workplace. New York: Lexington Books.

Sluss, D. M. ve Ashforth, B. E. (2008). How relational and organizational identification converge: Processes and conditions, Organization Science, 19(6), 807-823. 


\section{S. Aksoy Kürü 12/4 (2020) 3895-3913}

Sobel, M. E. (1982). Asymptotic confidence intervals for indirect effects in structural equation models. Sociological Methodology, 13, 290-312.

Srivastava, U. R. (2015). Multiple Dimensions of Organizational Justice and Work-Related Outcomes among Health-Care Professionals, American Journal of Industrial and Business Management, 5(11), 666-685.

Sweeney, P.D. ve McFarlin, D. B. (1997). Process and outcomes: Gender Differences in assessment of justice, Journal of Organizational Behavior, 18, 83-98.

Tajfel, H. (1978). Social Categorization, Social İdentity, And Social Comparison, H. Tajfel (Ed.), Differantiation Between social groups. Studies in The Social Psychology of Intergroup Relations, London, Academic Press, 61-76.

Tajfel, H. ve Turner, J. C. (1986). The social Identity Theory Of Intergroup Behaviour, S. WORCHEL \& W. G. AUSTIN (Ed.), Psychology of Intergroup Relations, Chicago, IL, Nelson, 7-24.

Tak, B. ve Aydemir, B. A. (2004). Örgütsel özdeşleşme üzerine iki görgül çalışma, 12. Ulusal Yönetim ve Organizasyon Kongresi, Uludağ Üniversitesi, Bursa.

Tang, T. L., Sarsfield B. ve Linda J. (1996). Distributive and procedural justice as related to satisfaction and commitment, Advanced Management Journal, 61, 155-178.

Taşlıyan, M., Hırlak, B., Çiftçi, G. E. ve Yılmaz, Ö. İ. (2017). Farklılık yönetiminin örgütsel adalet algısı ve örgütsel özdeşleşme üzerine etkisi: İç Anadolu ve Akdeniz Bölgesinde yer alan üniversitelerde karşılaştırmalı bir araştırma, Akademik Araştırmalar ve Çalışmalar Dergisi, 9(16), 1-19.

Taylor, M. S., Tracy, K. B., Renard, M. K., Harrison, J. K. ve Carroll, S. J. (1995). Due process in performance appraisal: a quasi-experiment in procedural justice, Administrative Science Quarterly, 40, 495-523.

Thibaut, J. ve Walker, L. (1975). Procedural Justice: a Psychological Analysis. Hillsdale, Nj: Erlbaum.

Thibaut, J. ve Walker, L. (1978). A Theory of procedure, California Law Review, 66.

Tornblom, K. Y. (1990). The Social Psychology of Distributive Justice içinde Scherer K.(Ed), The Nature and Administration of Justice: Interdiciplinary Approaches. Cambridge, England: Cambridge University Pres.

Tuna, M., Bircan, H. ve Yeşiltaş, M. (2012). Etik liderlik ölçeği'nin geçerlilik ve güvenilirlik çalışması: Antalya örneği. Atatürk Üniversitesi İktisadi ve İdari Bilimler Dergisi, 26(2), 143-155.

Türk Dil Kurumu, (2020). https://sozluk.gov.tr/?kelime=POLİTiKA (Erişim tarihi: 23 Şubat 2020).

Uğurlu, C. T. ve Üstüner, M. (2011). Öğretmenlerin örgütsel bağllllk düzeylerine yöneticilerinin etik liderlik ve örgütsel adalet davranışlarının etkisi, Hacettepe Üniversitesi Eğitim Fakültesi Dergisi, 41(41), 434-448.

Van Dick, R., Wagner U. Stellmacher, J. ve Christ, O. (2004). The utility of a broader conceptualization of organizational identification: Which aspects really matter? Journal of Occupational and Organizational Psychology, 77, 171-191.

Van Knippenberg, D. (2000). Work motivation and performance: A social identity perspective: An international review, Applied Psychology, 49, 357-371.

Van Knippenberg, D. ve Van Schie, E. C. M. (2000). Foci and correlates of organizational identification, Journal of Occupational and Organizational Psychology, 73, 137-147.

Welbourne, T., Balkin, D. B. ve Gomez Meija, L. R. (1995). Gainsharing and mutual monitoring: A Combined agency organizational justice interpretation, Academy of Management Journal, 38(3), 818-834.

Yeşiltaş, M. (2012). Örgütsel Özdeşleşmenin Oluşmasında Belirleyiciler Olarak Etik Liderlik ve Etik İklim: Otel İşletmelerine Yönelik Bir Uygulama. Yayımlanmamış Doktora Tezi. Gazi Üniversitesi Eğitim Bilimleri Enstitüsü Turizm İşletmeciliği Eğitimi Anabilim Dalı, Ankara.

Yılmaz, E. (2006). Okullardaki Örgütsel Güven Düzeyinin Okul Yöneticilerinin Etik Liderlik Özellikleri ve Bazı Değişkenler Açısından İncelenmesi. Yayınlanmamış Doktora Tezi, Selçuk Üniversitesi, Sosyal Bilimler Enstitüsü, Konya. 